\title{
The early adulthood of the Asia Pacific Journal of Management: A literature review 2005-2014
}

\author{
Cristina López-Duarte ${ }^{1}$ - Marta M. Vidal-Suárez ${ }^{1}$. \\ Belén González-Díaz ${ }^{2}$
}

Published online: 9 February 2018

(C) Springer Science+Business Media, LLC, part of Springer Nature 2018

\begin{abstract}
This research represents a comprehensive review of the articles published in the Asia Pacific Journal of Management (APJM) between 2005 and 2014, the journal's early "adulthood." It provides an overview of the evolution of this body of research across different dimensions: types of articles, international scope of the research, contributing scholars and institutions, scientific collaboration and non-academic cooperation paths as APJM developed as an Academy of Management associated journal. It also analyzes the impact of its published articles on the research field - based on traditional direct, indirect, and weighted impact measurements as well as on alternative metrics - and the journal's performance. APJM's early adulthood was featured by rapid and positive changes in terms of numbers, reach, international scope, scientific collaboration, article impact, and overall journal performance. Furthermore, the journal is currently ranked among the better management journals worldwide and has become the first among all management journals with a declared regional focus. Some hurdles remain and new challenges must be faced; among them, increasing the volume of conceptual works and developing the journal's scope by publishing a higher number of pieces of research dealing with organization and management issues relevant from a global (not only regional) perspective and continuing the journal's general improvement and growth.
\end{abstract}

Marta M. Vidal-Suárez

mmvidal@uniovi.es

Cristina López-Duarte

clduarte@uniovi.es

Belén González-Díaz

bgonzal@uniovi.es

1 Department of Business, Fc Commerce, Tourism and Social Sciences, University of Oviedo, Av. Luis Moya, 33203 Gijón, Asturias, Spain

2 Department of Accountancy, Fc Commerce, Tourism and Social Sciences, University of Oviedo, Av. Luis Moya, 33203 Gijón, Asturias, Spain 
Keywords Asia Pacific Journal of Management - Literature review · Journal article impact · International scope $\cdot$ Journal metrics

Since its founding in 1983 at the National University of Singapore, the Asia Pacific Journal of Management (APJM) has been a leading outlet and a major vehicle for the exchange of ideas and research among management scholars interested in the Asia-Pacific (AP) region (Ahlstrom, 2010; Carney, 2013; Delios, 2005; Peng, 2008). In 2002 it became the official journal of the Asia Academy of Management, the Asia affiliate of the Academy of Management (Singh, 2002). Following a mission statement of publishing "empirical or conceptual research which improves a broad understanding of what determines firm success," it has been publishing management and organization research relevant to the AP region for more than 30 years and it has become the world's longest running and most prominent academic journal of management that is "in Asia, on Asia, and of Asia" (Peng, 2007a: 385). In brief, APJM is a platform for researchers interested in Asia-related organizational issues, scholarship, and empirical evidence (Lau, 2007).

As a body of literature evolves, it is useful to step back and analyze its development and impact (Acedo \& Casillas, 2005; Peng \& Zhou, 2006). A review of the research published by APJM in its first years (its "childhood") was published by Ang in 1997, followed by a review focused on the journal's "adolescence" (Pleggenkuhle-Miles, Aroul, Sun, \& Su, 2007). The current work reviews the research published in APJM between 2005 and 2014 (inclusive), a decade that can be labeled as the journal's early "adulthood." The journal's first selection for coverage in the Web of Science-Social Science Citation Index (WOS-SSCI) in 2008 (first official impact factor for 2010) is a relevant milestone in this stage - see Table 1 . Therefore, our study covers the five-year periods prior to and following the journal's first SSCI assessment.

Our main objective is to analyze the literature published in APJM throughout this decade across different dimensions. More specifically, we address the following questions:

- What type of articles have been published in APJM?

- What is the scope of the research published in the journal?

- What is the reach of the journal in terms of scholars, institutions, and countries?

- Who are the most prolific individual and institutional contributors to APJM?

- What is the role played by scientific collaboration, non-academic cooperation, and funding-support on published research?

- How has the journal's performance evolved over the analyzed decade?

- What is the impact of the articles published by APJM on the research field?

This article is organized as follows: the next section describes the methodology used in the review, followed by a descriptive analysis of the different issues addressed in our research-kind of articles, scope of the research, reach in terms scholars and institutions, scientific collaboration and funding support patterns, and articles' impact on the research field based on direct, indirect, weighted, and early citation counts, as well as on altmetrics. In the last section we discuss and reflect on the evolution of this body of research by analyzing the results shown in the descriptive section, comparing them with those in previous reviews, and reflecting on their implications in terms of the journal's

${ }^{1}$ An overview of the journal's history can be found in Delios (2005), Lee (2007), and Lim (2007). 
Table 1 Breakdown of items published by APJM (2005-2014) and journal metrics

\begin{tabular}{|c|c|c|c|c|c|c|c|c|c|}
\hline \multirow[t]{2}{*}{ Year } & \multirow{2}{*}{$\begin{array}{l}\text { Documents/ } \\
\text { Year }\end{array}$} & \multicolumn{4}{|c|}{ Document type } & \multicolumn{4}{|c|}{ Journal metrics } \\
\hline & & $\begin{array}{l}\text { Original } \\
\text { papers }\end{array}$ & Reviews & Perspectives & Others & $\begin{array}{l}\text { JCR In } \\
\text { Factor }^{\mathrm{a}}\end{array}$ & & SJR In & ator $^{b}$ \\
\hline 2005 & 23 & 20 & 0 & 0 & 3 & & & .785 & $\mathrm{Q} 1^{\mathrm{c}}$ \\
\hline 2006 & 31 & 20 & 3 & 4 & 4 & & & .834 & $\mathrm{Q} 1^{\mathrm{d}}$ \\
\hline 2007 & 35 & 17 & 4 & 6 & 8 & & & 1.161 & Q1 \\
\hline 2008 & 36 & 27 & 1 & 3 & 5 & & & 1.309 & Q1 \\
\hline 2009 & 38 & 27 & 2 & 2 & 7 & & & 1.722 & $\mathrm{Q} 1$ \\
\hline 2010 & 41 & 33 & 0 & 2 & 6 & 3.355 & Q1 & 1.376 & Q1 \\
\hline 2011 & 41 & 34 & 2 & 1 & 4 & 3.062 & Q1 & 1.295 & Q1 \\
\hline 2012 & 57 & 47 & 2 & 3 & 5 & 4.099 & Q1 & 1.627 & Q1 \\
\hline 2013 & 63 & 51 & 2 & 4 & 6 & 2.742 & Q1 & 1.838 & Q1 \\
\hline 2014 & 48 & 43 & 1 & 2 & 2 & 2.091 & Q1 & 1.223 & Q1 \\
\hline Total & 413 & 319 & 17 & 27 & 50 & & & & \\
\hline
\end{tabular}

Prepared by the authors based on APJM, Web of Science, and Scimago Journal \& Country Rank

${ }^{\text {a }}$ Category: Management

b Subject areas: Business and International Management; Strategy and Management; Economics, Econometrics and Finance

c Ranked above the first quartile

d All subject areas except Strategy and Management (Q2)

performance during the analyzed decade (e.g., metrics, numbers, quality and reputation), its international/global reach and scope, and its influence on the academic research field and on non-academic audiences.

\section{Methods}

As a first step we compiled a comprehensive database gathering together the 413 different items published by APJM between 2005 and 2014, both inclusive (see Table 1). During this decade, APJM published 40 issues (4 issues per year); 10 of which were Special Issues on a variety of research topics of high relevance to Asia, such as the role of networks, conglomerates, and business groups in the AP region; knowledge, strategic, and "ethnic" management of AP firms; distinctive features of corporate governance, leadership, and favors management within the region; and the analysis of different types of Asian capitalism (see Table 2).

We then selected research articles/original papers (319), reviews (17), and perspectives (27). Therefore, commentaries, book reviews, introductions to Special Issues, and editorials are not included in the final database. The total number of articles published in this period (363, an average of over 36 articles per year) was much higher than in previous ones, ${ }^{2}$ with a sharp increase in the second half of the period, once APJM was selected for coverage in the SSCI.

\footnotetext{
${ }^{2}$ As shown in Ang (1997) and Pleggenkuhle-Miles et al. (2007), the average number of articles was 15.7 in the 1983-1996 period and 22.3 in the 1997-2006 one.
} 
Table 2 Special issues published by APJM (2005-2014)

\begin{tabular}{|c|c|c|c|}
\hline Year & Issue & Special Issue & Editors \\
\hline 2005 & 4 & Networks in Asia Pacific business & Dacin, T., \& Delios, A. \\
\hline 2006 & 4 & $\begin{array}{l}\text { Conglomerates and business groups } \\
\text { in the Asia Pacific }\end{array}$ & Peng, M. W., \& Delios, A. \\
\hline 2007 & 4 & 25th Anniversary & Peng, M. W. \\
\hline 2008 & 3 & $\begin{array}{l}\text { Knowledge management and innovation } \\
\text { strategy in the Asia Pacific }\end{array}$ & Lu, Y., Tsang, E. W. K., \& Peng, M. W. \\
\hline 2009 & 3 & $\begin{array}{l}\text { Varieties of Asian capitalism: } \\
\text { Indigenization and internationalization }\end{array}$ & Carney, M., Gedajlovic, E., \& Yang, X. \\
\hline 2010 & 3 & Managing in ethnic Chinese communities & Ahlstrom, D., Chen, S.-j., \& Yeh, K. S. \\
\hline 2011 & 1 & $\begin{array}{l}\text { Managing corporate governance globally: } \\
\text { An Asia Pacific perspective }\end{array}$ & Globerman, S. Peng, M. W., \& Shapiro, D. M. \\
\hline 2012 & 2 & Leadership in Asia & Lam, L. W., Huang, S., \& Lau, D. C. \\
\hline 2013 & 2 & Managing favors in a global economy & Puffer, S. M., McCarthy, D. J., \& Peng, M. W. \\
\hline 2013 & 3 & $\begin{array}{l}\text { Strategic management in private and } \\
\text { family businesses }\end{array}$ & Lu, Y., Au, K., Peng, M. W., \& Xu, E. \\
\hline
\end{tabular}

Prepared by the authors based on APJM

Data relative to each article were collected and categorized by author/s, authors' institutional affiliation at the time of publication, institutions' host countries, and year. Additional information relative to the type of article (conceptual/empirical), its scope, and financial support to the research published was also compiled in the database. Then, information relative to direct, indirect, and weighted citation, as well as to altmetrics, was gathered.

\section{Descriptive approach}

Type of articles and scope of the research published in APJM.

Almost $75 \%$ of the articles are empirical ones, while the remaining quarter deals with conceptual developments, perspectives and reflections, and literature reviewsthis is a tendency similar to that shown by the journal in previous stages. Among empirical studies, there is a clear predominance of quantitative methods. The qualitative approach is used in barely $12 \%$ of the empirical articles and in most cases it relies on case studies. Both, the percentage of empirical articles and the volume of works that rely on quantitative methods are higher in the 2010-2014 sub-period than in the previous period. Although the journal mission statement refers to both empirical and conceptual research, quantitative empirical articles are clearly predominant, even more so since the journal was selected for coverage in SSCI. This is a tendency shown in other top-tier business and management journals (Welch, Plakoyiannaki, Piekkari, \& Paavilainen-Mäntymäki, 2013), as qualitative empirical studies and conceptual articles that propose and develop theoretical frameworks without testing the validity of their proposals usually face greater publishing difficulties in this kind of journal.

It is worth noting that up to $70 \%$ of the articles focus their study (whether an empirical analysis or a conceptual development) on just one country and an additional $6 \%$ on bilateral relations/issues. China is undoubtedly the key country covered in the journal's research, with almost $60 \%$ of these articles on China, and over $70 \%$ if we 
consider the Greater China region comprising Mainland China, Hong Kong, Macau, and Taiwan. Scholarly interest in China's economic growth, its distinctive political/ institutional features and changes, its key role as an international player and numerous active research schools in the Greater China region have all driven APJM's publishing path over the analyzed period. Japan and South Korea comprise a distant $7 \%$ each and India a scarce 4\% - though the attention paid to these countries was lower in the previous stage (Pleggenkuhle-Miles et al., 2007), and a Special Issue was published on India and innovation recently, after the period under study (Jain, Nair, \& Ahlstrom, 2015; Prabhu \& Jain, 2015). Research focused on other AP countries is not so extensive; however, the range of researched nation-states includes countries already analyzed in previous stages - Australia, Indonesia Malaysia, New Zealand, Singapore, Thailand, and Vietnam as well as "new" countries, among them, Iran, Pakistan, the Philippines, and Russia, pointing to a more Asia-wide perspective further encompassing Central and West Asia (e.g., Ismail \& Ford, 2010). The remaining articles deal with organization and management issues relevant to the AP area as a whole and/or without any kind of regional context, thus giving a global perspective or scope.

\section{Authors and institutions}

Tables 3 and 4 include information about the number of published articles by scholars and institutions. For each of the 363 articles within the database we recorded information about the authors, their institutional affiliation at the time of publication, and the home country of each individual institution, considering both academic and nonacademic institutions. For each individual author or institution we examined both total and fractional (or adjusted) counting (Glänzel, 2001). The adjusted contribution takes into account the number of different co-authors in an article; therefore, it is adjusted according to that portion of the article attributable to the scholar/institution alone.

Following prior research (e.g., Knight, Hult, \& Bashaw, 2000; Kumar \& Kundu, 2004; Quer, Claver, \& Rienda, 2007, Treviño, Mixon, Funk, \& Inkpen, 2010), if an article was co-authored by more than one author from the same institution, then the institution was credited with one appearance (total or adjusted) per author, and if an author listed multiple institutional affiliations, full credit (total or adjusted) was given to each institution; and finally, no distinction was made regarding the order of appearance of scholars.

A total of 666 different authors and 335 institutions are involved in the set of selected articles. A mere 5\% of the latter are non-academic institutions. Almost $80 \%$ of the authors and $56 \%$ of the academic institutions contributed only one article (absolute counting). Neither the authors' nor the institutions' distribution adjust to the Lotka or Square Root laws, ${ }^{3}$ pointing to a wider than expected range of scholars and institutions publishing their work in APJM.

\footnotetext{
${ }^{3}$ These are two different laws traditionally used in bibliometric studies to analyze the spread of different scholars contributing to a particular field/topic/journal (Glänzel \& Schubert, 1985). The Lotka's law states that (1) the number of authors making $n$ contributions is about $1 / n^{2}$ of those making one and (2) the proportion of all contributors that make a single contribution is about $60 \%$. The square root law states that half of the scientific papers within a selected set are contributed by the top square root of the total number of scientific authors.
} 
Table 3 Most prolific authors contributing to $A P J M(2005-2014)$
Prepared by authors

${ }^{a}$ Ranked by adjusted number of contributions (as first criterion) and by total contributions as second one

\begin{tabular}{|c|c|c|c|}
\hline $\operatorname{Rank}^{\mathrm{a}}$ & Authors & $\begin{array}{l}\text { Adjusted } \\
\text { contributions }\end{array}$ & $\begin{array}{l}\text { Total } \\
\text { contributions }\end{array}$ \\
\hline 1 & Peng, M. W. & 7.17 & 17 \\
\hline 2 & Tjosvold, D. & 4.08 & 11 \\
\hline 3 & Carney, M. & 2.83 & 4 \\
\hline 4 & Ralston, D. A. & 2.75 & 11 \\
\hline 5 & Chung, H.-M. & 2.50 & 3 \\
\hline $6-7$ & Beamish, P. W. & 2.33 & 4 \\
\hline $6-7$ & Li, P. P. & 2.33 & 3 \\
\hline $8-9$ & Tung, R. L. & 2.00 & 3 \\
\hline $8-9$ & Chen, M.-J. & 2.00 & 2 \\
\hline 10 & Li, Y. & 1.92 & 4 \\
\hline 11 & Tang. J. & 1.83 & 3 \\
\hline 12 & Syed, J. & 1.75 & 3 \\
\hline $13-14$ & $\mathrm{Li}, \mathrm{Y}$ & 1.67 & 6 \\
\hline $13-14$ & Tsang, E. W. K. & 1.67 & 3 \\
\hline $15-22$ & Sun, S. L. & 1.50 & 5 \\
\hline $15-22$ & Wong, A. & 1.50 & 4 \\
\hline $15-22$ & Wu, J. & 1.50 & 3 \\
\hline $15-22$ & Zhou, J. Q. & 1.50 & 3 \\
\hline $15-22$ & Brookfield, J. & 1.50 & 2 \\
\hline $15-22$ & Chu, W. & 1.50 & 2 \\
\hline $15-22$ & Dieleman, M. & 1.50 & 2 \\
\hline $15-22$ & Meyer, K. E. & 1.50 & 2 \\
\hline 23 & Law, K. S. & 1.42 & 4 \\
\hline 24 & Loi, R. & 1.37 & 4 \\
\hline $25-31$ & Bruton, G. D. & 1.33 & 4 \\
\hline $25-31$ & Chen, G. & 1.33 & 3 \\
\hline $25-31$ & $\mathrm{Li}, \mathrm{J}$. & 1.33 & 3 \\
\hline $25-31$ & McGuire, J. & 1.33 & 3 \\
\hline $25-31$ & Lahiri, S. & 1.33 & 2 \\
\hline $25-31$ & Tipton, F. B. & 1.33 & 2 \\
\hline $25-31$ & $\mathrm{Xu}, \mathrm{D}$. & 1.33 & 2 \\
\hline
\end{tabular}

As shown in Table 3, Mike W. Peng, Dean Tjosvold, and Michael Carney are among the top 10 authors, considering both raw and adjusted counting, who contribute more than 2.8 times (adjusted contribution) to $A P J M$ in the analyzed period. Some prolific authors like Yuan Li and Sunny Li Sun are among the top 10 when only considering raw contributions, but are in lower positions when considering adjusted contributions, pointing to publishing patterns related to scientific collaboration in large research networks. Conversely, other authors like Hsi-Mei Chung, Paul W. Beamish, Peter Ping Li, Ming-Jer Chen, Rosalie L. Tung, and Yan Li are at the top of the list in adjusted (but not in raw) contributions pointing to smaller teams ${ }^{4}$ or even single authorship. ${ }^{5}$ It is worth mentioning that some of these authors (e.g., Mike W. Peng, Michael Carney, Dean Tjosvold) were also key contributors in earlier stages as shown in PleggenkuhleMiles et al. (2007). The magnitude of contribution of most prolific authors can best be viewed in comparison to the average appearance of .54 .

\footnotetext{
${ }^{4}$ E.g., Li, Ahlstrom, and Ashkanasy (2010); Li, Chun, Ashkanasy, and Ahlstrom (2012); Peng and Beamish (2014).

${ }^{5}$ E.g., Li (2007); Li (2011). 
Table 4 Most prolific institutions contributing to APJM (2005-2014)

\begin{tabular}{|c|c|c|c|c|}
\hline $\operatorname{Rank}^{\mathrm{a}}$ & Institutions & Country & $\begin{array}{l}\text { Adjusted } \\
\text { contributions }\end{array}$ & $\begin{array}{l}\text { Total } \\
\text { contributions }\end{array}$ \\
\hline 1 & Chinese University of Hong Kong & Hong Kong & 17.15 & 50 \\
\hline 2 & Xi'an Jiaotong University & China & 16.92 & 57 \\
\hline 3 & University of Texas at Dallas & US & 13.50 & 36 \\
\hline 4 & National University of Singapore & Singapore & 8.85 & 17 \\
\hline 5 & Lingnan University & Hong Kong & 8.75 & 25 \\
\hline 6 & University of Macau & Macau & 6.70 & 18 \\
\hline $7-8$ & Hong Kong Baptist University & Hong Kong & 6.58 & 19 \\
\hline $7-8$ & City University of Hong Kong & Hong Kong & 6.58 & 18 \\
\hline 9 & Simon Fraser University & Canada & 5.69 & 14 \\
\hline 10 & University of Hong Kong & Hong Kong & 5.08 & 9 \\
\hline 11 & Hong Kong Polytechnic University & Hong Kong & 4.75 & 13 \\
\hline 12 & University of Sydney & Australia & 4.50 & 10 \\
\hline 13 & National Taiwan University & Taiwan & 4.33 & 8 \\
\hline 14 & Concordia University & Canada & 3.83 & 6 \\
\hline 15 & I-Shou University & Taiwan & 3.75 & 5 \\
\hline 16 & University of Western Ontario & Canada & 3.70 & 8 \\
\hline 17 & Shanghai Jiao Tong University & China & 3.50 & 11 \\
\hline 18 & Seoul National University & South Korea & 3.35 & 11 \\
\hline $19-20$ & National Sun Yat-sen University & Taiwan & 3.25 & 8 \\
\hline $19-20$ & California State University & US & 3.25 & 7 \\
\hline 21 & Korea University & South Korea & 3.17 & 5 \\
\hline 22 & Chinese Academy of Sciences & China & 2.94 & 11 \\
\hline $23-24$ & University of London & UK & 2.83 & 6 \\
\hline $23-24$ & Saint Louis University & US & 2.83 & 5 \\
\hline 25 & Renmin University of China & China & 2.70 & 8 \\
\hline 26 & Erasmus University Rotterdam & Netherlands & 2.67 & 7 \\
\hline $27-28$ & Arizona State University & US & 2.50 & 6 \\
\hline $27-28$ & Hong Kong University of Science \& Technology & Hong Kong & 2.50 & 6 \\
\hline 29 & Sun Yat-sen University & China & 2.43 & 8 \\
\hline 30 & University of New South Wales & Australia & 2.33 & 6 \\
\hline
\end{tabular}

Prepared by authors

${ }^{\text {a }}$ Ranked by adjusted number of contributions (as first criterion) and by total contributions as second one

The rankings of most prolific institutions (both raw and adjusted) are led by The Chinese University of Hong Kong, the Xi' an Jiaotong University (China), the University of Texas in Dallas (US), the National University of Singapore, the Lingnan University (Hong Kong), the University of Macau, Hong Kong Baptist University, City University of Hong Kong, and Simon Fraser University (Canada). In addition, Hong Kong Polytechnic University and University of Hong Kong enter the top 10 when considering total or adjusted contributions respectively. Some of these institutions entered this top-10 ranking during the analyzed decade (e.g., the University of Texas at Dallas, the University of Macau, or Simon Fraser University), while some others were already key players in previous stages (e.g., The Chinese University of Hong Kong, Xi'an Jiaotong University, National University of Singapore, Lingnan University, Hong Kong Baptist University, and City University of Hong Kong).

The contributing institutions are located in 32 different countries, pointing to an increase in the international scope of the authorship - as shown in Ang (1997) and 
Pleggenkuhle-Miles et al. (2007), country affiliations were 24 and 27 in the journal's childhood and adolescence, respectively. Not surprisingly, AP institutions keep dominating the research published in APJM - over $60 \%$ of total contributions - while North American ones are a long way back in second place with a modest $30 \%$ representation. Conversely, European institutions play a clearly minor role. There is a steady increase in non-US scholars publishing in APJM; this is a trend noted by Ang (1997) and later confirmed by Pleggenkuhle-Miles et al. (2007). Chinese institutions (coming from both Mainland China and Greater China) and American institutions are the most prolific contributors to APJM. Among the European institutions, the English and Dutch ones are the major contributors to the journal.

\section{Scientific collaboration and research funding support}

Collaborative research plays an important role in the production and dissemination of scientific knowledge (Beaver, 2004). The development of collaborative networks facilitates access to resources and data, increases efficiency, allows bigger challenges to be faced, and/or improves scholars' prestige and visibility (Beaver, 2001). In his 1997 review, Ang pointed to the interest of increasing collaborative research in Asian management studies as a way to overcome time and resource constraints and deal with the complexity of the Asian environment.

Following Ang (1997) and Pleggenkuhle-Miles et al. (2007) scientific collaboration has been undertaken through co-authorship. About $18 \%$ of the articles gathered in the database are single-authored, pointing to a relevant and steady increase in collaborative research when compared to previous stages; the percentage of single-authored articles was over $40 \%$ in the journal's childhood (Ang, 1997) and over 35\% in the journal's adolescence (PleggenkuhleMiles et al., 2007). Furthermore, statistically significant differences can be found when comparing collaboration patterns within the two different five-year sub-periods analyzed in our study. As shown in Table 5, the number of co-authored articles is higher than expected within the second sub-period, pointing to a stronger role of collaborative research.

Tables 6 and 7 show information relative to team size and scope. Our analysis points to a particularly high number of multi-authored articles, as at least three researchers collaborate in over $50 \%$ of the co-authored articles - much higher than in previous stages. Larger teams play a (statistically significant) more active role within the second sub-period. International collaboration (e.g., research networks whose authors' institutional affiliation includes different countries) is the outstanding type of collaboration throughout the whole analyzed period - over $55 \%$ of the co-authored articles gathered in the database reflect this international pattern. Among them, there is a majority of articles that reflect inter-regional

Table 5 Scientific collaboration path 2005-2014

\begin{tabular}{llll}
\hline & $2005-2009$ & $2010-2014$ & Total 2005-2014 \\
\hline Single author & 39 & 26 & 65 \\
& $28.7 \%$ & $11.5 \%$ & $17.9 \%$ \\
& $(4.1)$ & $(-4.1)$ & \\
Co-authorship & 97 & 201 & 298 \\
& $71.3 \%$ & $88.5 \%$ & $82.1 \%$ \\
Total & $(-4.1)$ & $(4.1)$ & \\
\hline
\end{tabular}


Table 6 Scientific collaboration: Size of the network

\begin{tabular}{|c|c|c|c|c|}
\hline & \multirow{4}{*}{2 authors } & & & \\
\hline & & 52 & 85 & 137 \\
\hline & & $53.6 \%$ & $42.3 \%$ & $46.0 \%$ \\
\hline & & $(1.8)$ & $(-1.8)$ & \\
\hline & \multirow[t]{3}{*}{3 authors } & 37 & 74 & 111 \\
\hline & & $38.1 \%$ & $36.8 \%$ & $37.2 \%$ \\
\hline & & -.2 & $(-.2)$ & \\
\hline & \multirow[t]{3}{*}{4 or more authors } & 8 & 42 & 50 \\
\hline & & $8.2 \%$ & $20.9 \%$ & $16.8 \%$ \\
\hline nil: $8.09 \%$ (adjusted residuals in & & $(-2.7)$ & $(2.7)$ & \\
\hline$* n<1 . * * n<05 \cdot * * * n<01$ & Total & 97 & 201 & 298 \\
\hline
\end{tabular}

cooperation, that is, research networks whose authors' institutional affiliation includes different regions, with collaboration among AP and North American authors being the most salient (over $60 \%$ of inter-regional cooperation). Co-authorship networks among AP and European partners are less common (about $20 \%$ of inter-regional co-authorship), while cooperation among North American and European partners is the least common type (about 10\%). Finally, only seven articles reflect inter-regional ties that include the three key regions (AP, North America, and Europe).

Both intramural (e.g., networks participated in by authors affiliated to the same institution) and national collaboration (e.g., networks whose authors' institutional affiliation includes different institutions, but only one country) also play a relevant role as $46 \%$ of the set of co-authored articles show some degree of intramural cooperative ties and more than $43 \%$ of them show national cooperation. The latter is more salient (in a statistically significant way) in the second sub-period. As shown in Fernández, Ferrándiz, and León (2016), both organizational proximity (e.g., same/similar regulations and routines) and institutional proximity (e.g., same/similar laws, policies, culture, and language) foster scientific collaboration. Conversely, collaboration with nonacademic institutions is extremely scarce, although it is more salient within the second sub-period.

As shown in Ebadi and Schiffauerova (2016), researchers and their projects are highly dependent on funding; in addition, supporting funding programs lead to a higher quality of publication. Thus, we analyzed the funding patterns underlying the research articles published in APJM. As shown in Table 8, one-third of the analyzed articles is related to funded research projects and/or grants. The percentage of financially supported studies is higher during the second sub-period and it is highly correlated to scientific collaboration - the latter is a trend already shown in other fields (e.g., Adams, Black, Clemmons, \& Stephan, 2005; Ebadi \& Schiffauerova, 2016).

\section{An overview of APJM's performance based on journal metrics}

Journal metrics provide an assessment of a journal's performance in terms of significance, role, and position in the international formal communication network, as well as in terms of quality and prestige as perceived by scholars (Glänzel \& Moed, 2002). Although different journal metrics exist such as the broader Google Scholar, Scopus and the Web of Science measurements have traditionally been considered the "gold standard" for citation analysis (Harzing 
Table 7 Scientific collaboration: Scope of the network

\begin{tabular}{|c|c|c|c|}
\hline & 2005-2009 & $2010-2014$ & Total 2005-2014 \\
\hline Intra-uni cooperation & $\begin{array}{l}43 \\
44.3 \% \\
(-.4) \\
\mathrm{Chi}^{2}: .56(\mathrm{a}\end{array}$ & $\begin{array}{l}94 \\
46.8 \% \\
(.4) \\
\text { uals in paren }\end{array}$ & $\begin{array}{l}137 \\
46.0 \%\end{array}$ \\
\hline National cooperation & $\begin{array}{l}35 \\
36.1 \% \\
(-1.8) \\
\text { Chi }^{2}: 3.326\end{array}$ & $\begin{array}{l}95 \\
47.3 \% \\
(1.8) \\
\text { esiduals in pa }\end{array}$ & $\begin{array}{l}130 \\
43.6 \%\end{array}$ \\
\hline International cooperation & $\begin{array}{l}50 \\
51.5 \% \\
(-.9) \\
\mathrm{Chi}^{2}: .85(\mathrm{a}\end{array}$ & $\begin{array}{l}115 \\
57.2 \% \\
(.9) \\
\text { uals in paren }\end{array}$ & $\begin{array}{l}165 \\
55.4 \%\end{array}$ \\
\hline Non academic cooperation & $\begin{array}{l}2 \\
2.1 \% \\
(-1.4) \\
\text { Chi }^{2}: 1.824\end{array}$ & $\begin{array}{l}9 \\
4.5 \% \\
(1.4) \\
\text { siduals in par }\end{array}$ & $\begin{array}{l}11 \\
3.7 \%\end{array}$ \\
\hline Total cooperation & 97 & 201 & 298 \\
\hline
\end{tabular}

$* p<.1 ; * * p<.05 ; * * * p<.01$

\& Alakangas, 2016). Based on citation counts to the set of articles published by the journal, the Scimago Journal Rankings (SJR) provided by Scopus and the Journal Citation Reports (JCR) by the WOS-SSCI all measure the frequency with which the average article in the journal has been cited by the research community over a given period. ${ }^{6}$

APJM has been tracked by Scopus since 1983 (first SJR impact factor in 1999); therefore, it has been included in SJR rankings over all the analyzed period. The journal SJR indicator improved from .785 in 2005 to 1.223 in 2014, reaching its highest values in 2013 (1.838), 2009 (1.722), and 2012 (1.627). Its ranking remained above the SJR index first quartile during the whole period (see Table 1). The journal got its first JCR impact factor for the year 2010. Moreover, it achieved a ranking above the first quartile in 2010 and it kept this position until the end of the analyzed period-the journal achieved its highest JCR impact factor in 2012 (4.099) getting to be ranked above the index's first decile.

Getting such high Scopus and SSCI recognitions is a huge achievement and a widely-accepted indicator of quality for a journal. In the following section we provide information on the particular articles contributing most to this recognition (e.g., the articles having the strongest impact on the research field in terms of citations counts).

\footnotetext{
${ }^{6}$ The JCR annual-impact factor is a ratio between current year citations to any item published in the journal during the previous two years and the total number of articles published by this journal in the same two-year period. The WOS-SSCI is the database used to gather citation counts. The SJR uses Scopus as a data source; therefore, it gathers citations from a wider number of journals than the JCR. It relies on three-year citations weighted by subject field and quality/influence of the citing journal (journals are considered to be influential if they are cited often by other influential journals).
} 
Table 8 Funding support to the research published in $A P J M$ (2005-2014)

$\mathrm{Chi}^{2}: 4.67 * *$ (adjusted residuals in parentheses)

$* p<.1 ; * * p<.05 ; * * * p<.01$
2005-2009 2010-2014 Total 2005-2014

\begin{tabular}{clll}
\hline Funded research & 37 & 87 & 124 \\
& $27.2 \%$ & $38.3 \%$ & $34.2 \%$ \\
& $(-2.2)$ & $(2.2)$ & \\
Non-funded research & 99 & 140 & 239 \\
& $72.8 \%$ & $61.7 \%$ & $65.8 \%$ \\
Total & $(2.2)$ & $(-2.2)$ & \\
\hline
\end{tabular}

\section{Article impact on the research field}

A traditional citation analysis has been performed in order to analyze article impact on the research field. Then we have complemented this analysis with a study based on alternative metrics. A citation analysis is a way to measure the actual impact of a particular article on its research field (Harzing \& van der Wal, 2008). Citation counts provide an indicator of the work's reception and use by colleagues (Glänzel \& Schoepflin, 1999); as pointed out by Kochen (1987), any citation of a piece of research reflects an explicit recognition of an intellectual debt. To assess the impact of the articles published by APJM we conducted a citation analysis up to December 31, 2016 using the Scopus database. ${ }^{7}$ Although we have allowed a minimum three-year period for articles to be cited, this analysis is somehow unfair on more recent articles. That is the rationale for (1) splitting the database in two different periods (2005-2009 and 2010-2014), (2) including the ratio of citations per year, considering the number of years since the article was published, (3) measuring the early citation for most recent articles (e.g., citation counts in the three-year period following each article publication, and (4) analyzing the article's field weighted citation impact (FWCI) and citation benchmark (CB).

\section{Direct and accumulated impact}

Tables 9 and 10 show the articles that comprise APJM's $h$-core in each sub-period. The $h$-core of a particular set of articles, also known as the $h$-classics (Martinez et al., 2014), is comprised of the $h$ highly cited papers with more than $h$ direct (first generation) citations received. ${ }^{8}$ APJM's $h$-core for the 2005-2009 period is comprised of 37 articles (about $27 \%$ of the articles published in the period that involve almost 2/3 of total citations counts), while the journal's h-core for 2009-2014 involves 24 articles (10\% of published articles representing more than $30 \%$ of total citation counts).

As shown in the Table 9, the review by Mathews (2006), dealing with the role of dragon multinationals (e.g., multinationals from the AP) as new players and challengers in the global arena, is the most cited work. Although focused on different specific

\footnotetext{
7 This is one the most commonly used sources of bibliometric data traditionally used in many international rankings of universities (Harzing \& van der Wal, 2008).

${ }^{8}$ The classical $h$-index was introduced by Hirsch in 2005 . It was initially employed for individuals and defined as "a scientist has index $h$ if $h$ of her/his papers have at least $h$ citations each" (Hirsch 2005: 16,569). The set of articles occupying the first $h$ ranks constitutes the so-called $h$-core (Rosseau 2006), that is, a group of highperformance publications (in terms of citation) with respect to the scientist's career (Jin, Avery \& Bergsteiner, 2007). Researchers have extended the application of the $h$-index to other units such as journals, institutions, and topics.
} 
Table 9 h-core (2005-2009). Total citation counts and SP H Index

\begin{tabular}{|c|c|c|c|c|}
\hline Rank $^{a}$ & Article & Year & $\begin{array}{l}\text { Total } \\
\text { citations }^{b}\end{array}$ & SP $h$-index \\
\hline 1 & Mathews, J. A. & 2006 & 574 & 46 \\
\hline 2 & Meyer, K. E. & 2006 & 172 & 32 \\
\hline 3 & Dunning, J. H., \& Lundan, S. M. & 2008 & 166 & 24 \\
\hline 4 & Hofstede, G. & 2007 & 157 & 21 \\
\hline 5 & Peng, M. W., \& Zhou, J. Q. & 2005 & 149 & 31 \\
\hline 6 & Filatotchev, I., Lien, Y.-C., \& Piesse, J. & 2005 & 109 & 22 \\
\hline 7 & Huang, Q., Davison, R. M., \& Gu, J. & 2008 & 89 & 17 \\
\hline 8 & Peng, M. W. & 2005 & 77 & 20 \\
\hline 9 & Yeung, H. W. C. & 2006 & 74 & 20 \\
\hline 10 & Ahlstrom, D., Bruton, G. D., \& Yeh, K. S. & 2007 & 70 & 16 \\
\hline 11 & Li, J. J. & 2005 & 67 & 21 \\
\hline 12 & Su, Y.-S., Tsang, E. W. K., \& Peng, M. W. & 2009 & 66 & 11 \\
\hline 13 & Quer, D., Claver, E., \& Rienda, L. & 2007 & 63 & 19 \\
\hline 14 & Law, K. S., Wong, C.-S., Huang, G.-H., \& Li., X. & 2008 & 62 & 13 \\
\hline 15 & Globerman, S., \& Shapiro, D. & 2009 & 61 & 18 \\
\hline $16-17$ & Ma, X., Yao, X., \& Xi, Y. & 2006 & 60 & 20 \\
\hline $16-17$ & Bruton, G. D., Dess, G. G., \& Janney, J. J. & 2007 & 60 & 16 \\
\hline 18 & Chen, N. Y.-F., \& Tjosvold, D. & 2007 & 57 & 16 \\
\hline 19 & Zhou, K. Z., \& Li, C. B. & 2007 & 56 & 14 \\
\hline 20 & $\begin{array}{l}\text { Heugens, P. P. M. A. R., van Essen, M., \& } \\
\text { van Oosterhout, J. (Hans) }\end{array}$ & 2009 & 54 & 16 \\
\hline 21 & Yang, X., Jiang, Y., Kang, R., \& Ke, Y. & 2009 & 53 & 14 \\
\hline 22 & Wu, W.-P., \& Leung, A. & 2005 & 51 & 16 \\
\hline $23-24$ & Li, S., \& Scullion, H. & 2006 & 50 & 15 \\
\hline $23-24$ & Gao, S., Xu, K., \& Yang, J. & 2008 & 50 & 12 \\
\hline $25-26$ & Asakawa, K., \& Som, A. & 2008 & 49 & 10 \\
\hline $25-26$ & Yang, J. Y., \& Li, J. & 2008 & 49 & 10 \\
\hline 27 & Li, J., \& Kozhikode, R. K. & 2008 & 47 & 11 \\
\hline 28 & Kedia, B. L., Mukherjee, D., \& Lahiri, S. & 2006 & 46 & 15 \\
\hline $29-30$ & Collinson, S., \& Rugman, A. M. & 2007 & 44 & 15 \\
\hline $29-30$ & Zhang, J., \& Ma, H. & 2009 & 44 & 11 \\
\hline 31 & Huang, X., Shi, K.,Zhang, Z., \& Cheung, Y. L. & 2006 & 43 & 10 \\
\hline 32 & Hill, C. W. L. & 2007 & 42 & 12 \\
\hline 33 & Li, P. P. & 2007 & 41 & 8 \\
\hline $34-35$ & Lu, Y., \& Yao, J. & 2006 & 38 & 12 \\
\hline $34-35$ & Cuervo-Cazurra, A. & 2006 & 38 & 8 \\
\hline $36-37$ & He, Y., Tian, Z., \& Chen, Y. & 2007 & 37 & 14 \\
\hline $36-37$ & Chen, C.C., \& Chen, X.-P. & 2009 & 37 & 11 \\
\hline
\end{tabular}

Prepared by authors based on Scopus Database

${ }^{a}$ Ranked by total number of citations (excluded self-citation as first criterion) and by SP $h$-index as second one

${ }^{\mathrm{b}}$ Citations count up to December 31, 2016

issues and drawing from different perspectives, the articles by Dunning and Lundan (2008), Hofstede (2007), Meyer (2006) and Pen and Zhou (2005) place the emphasis on the institutional approach when developing research in business and management in the AP area. The work by Filatochev, Lien, and Piesse (2005) analyzing the performance of family-controlled firms is the last article receiving more than 100 citations. Additionally, four articles specifically focused on China and its different features and 
Table 10 h-core (2010-2014). Total citation counts and SP H Index

\begin{tabular}{|c|c|c|c|c|}
\hline $\operatorname{Rank}^{\mathrm{a}}$ & Article & Year & $\begin{array}{l}\text { Total } \\
\text { citations }^{\mathrm{b}}\end{array}$ & SP $h$-index \\
\hline 1 & Chen, Y. Y., \& Young, M. N. & 2010 & 83 & 19 \\
\hline $2-3$ & Estrin, S., \& Prevezer, M. & 2011 & 53 & 12 \\
\hline $2-3$ & Jiang, Y., \& Peng, M. W. & 2011a & 53 & 11 \\
\hline 4 & Zhu, Y., Wittmann, X., \& Peng, M. W. & 2012 & 50 & 6 \\
\hline $5-6$ & Chu, W. & 2011 & 48 & 11 \\
\hline $5-6$ & Li, P. P. & 2012 & 48 & 8 \\
\hline 7 & Cui, L., \& Jiang, F. & 2010 & 46 & 12 \\
\hline 8 & Hu, H. W., Tam, O. K., \& Tan, M. G.-S. & 2010 & 43 & 8 \\
\hline $9-10$ & Bhagat, R. B., McDevitt, A. S., \& McDevitt, I. & 2010 & 40 & 12 \\
\hline $9-10$ & Chen, V. Z., Li, J., \& Shapiro, D. M. & $2011 b$ & 40 & 10 \\
\hline 11 & Lin, J., \& Si, S. X. & 2010 & 39 & 9 \\
\hline 12 & Chen, Y., Friedman, F., Yu, E., \& Sun, F. & 2011a & 38 & 6 \\
\hline 13 & Peng, M. W., Li, Y. Xie, E., \& Su, Z. & 2010 & 37 & 7 \\
\hline 14 & Quer, D., Claver, E., \& Rienda, L. & 2012 & 34 & 8 \\
\hline 15 & Ahn, M. J. \& York, A. S. & 2011 & 33 & 5 \\
\hline 16 & $\begin{array}{l}\text { Young, M. N., \& Tsai, T., Wang, X., Liu, S., \& } \\
\text { Ahlstrom, D. }\end{array}$ & 2014 & 32 & 6 \\
\hline 17 & Jiang, Y., \& Peng, M. W. & $2011 b$ & 30 & 9 \\
\hline $18-19$ & Tung, R. S., \& Chung, H. F. L. & 2010 & 28 & 7 \\
\hline $18-19$ & Li, Y., Chen, H., Liu, Y., \& Peng, M. W. & $2014 b$ & 28 & 3 \\
\hline $20-22$ & Liden, R. C. & 2012 & 27 & 7 \\
\hline $20-22$ & Syed, J., \& Pio, E. & 2010 & 27 & 5 \\
\hline $20-22$ & $\begin{array}{l}\text { van Essen, M., van Oosterhout, J. (Hans), \& } \\
\text { Carney, M. }\end{array}$ & 2012 & 27 & 5 \\
\hline $23-24$ & Park, B. I. & 2010 & 25 & 7 \\
\hline $23-24$ & Gong, Y., Chow, I. H.-S., \& Ahlstrom, D. & 2011 & 25 & 5 \\
\hline
\end{tabular}

Prepared by authors based on Scopus Database

${ }^{a}$ Ranked by total number of citations (excluded self-citation as first criterion), and by SP $h$-index as second one

${ }^{\mathrm{b}}$ Citations count up to December 31, 2016

characteristics related to business management are among the top-10 most cited articles in the 2005-2009 period (Ahlstrom, Bruton, \& Yeh, 2007; Huang, Davison, \& Wu, 2008; Peng, 2005; Yeung, 2006).

The analysis of cross-border mergers and acquisitions by Chinese companies (Chen \& Young, 2010) is the most cited paper within the 2010-2014 period (see Table 10). The role of institutions remains a relevant issue among the most cited papers in these years (Cui \& Jiang, 2010; Estrin \& Prevezer, 2011; Zhu, Wittmann, \& Peng, 2012); however, other issues, such as the role of family ownership and management on firms ' performance and evolution (Chu, 2011; Jiang \& Peng, 2011a), and the different features of governance mechanisms in the AP region (Chen, Li, \& Shapiro, 2011b; Hu, Tam, \& Tan, 2010), arise among the works having the strongest impact on the research field. Within the top-10 list of most cited articles there are two works dealing with the need for developing management theories that are applicable in the Asian context and the role to be played by indigenous research (Bhagat, McDevitt, \& McDevitt, 2010; Li, 2012). These issues have been also addressed in more recent articles published in the journal (Li \& Ahlstrom, 2016). 
A direct (first generation) citation of an article shows the article's direct influence on its citing works. Therefore, direct citation counting is a basic indicator for assessing an article's first-level impact on its research field. However, to measure a work's actual or accumulated impact it becomes necessary to consider its indirect (further generations) citation. Indirect citations point to a connection (indirect influence) between the article under scrutiny and the works included in each generation of citations (Fragkiadaki \& Evangelidis, 2016). To measure the indirect impact of the set of articles in the $h$-core, we conducted an analysis of the second generation of citations and then identified each article's Single Publication $h$-index (SP $h$-index) as in Tables 9 and 10. The second generation of citations refers to citations received by the citing articles of the target one. ${ }^{9}$ The SP $h$-index is based on these citations and is defined as $h$ such that $h$ of the papers citing the target work have $h$ citations or more (Schubert, 2009). ${ }^{10}$ This measurement does not only assess the impact of an article, but also its centrality by considering the quality and quantity of its citing publications (Schubert, 2009). In other words, it evaluates if a particular article is cited by relevant articles. Therefore, it provides a more comprehensive and refined picture of the performance of an article (Bornmann, Mutz, Hug, \& Daniel, 2011).

Some articles show a sharp increase in impact on the research field when this index is employed. Such articles include the analysis of managerial networks of foreign firms in China (Li, 2005), the study of the relationship between business group affiliation and firm performance in transition economies (Ma, Yao, \& Xi, 2006), the review on business and management in China (Quer et al., 2007), the analysis of guanxi and social capital in China ( $\mathrm{Lin} \& \mathrm{Si}, 2010$ ), the study of main conflicts in corporate governance during times of economic crisis (Jiang \& Peng, 2011b), and the role played by political risk and cultural distance as drivers of outward Chinese foreign direct investment (Quer, Claver, \& Rienda, 2012).

\section{Per-year and early citation}

To do justice to most recent articles, it is advisable to measure the ratio of citations per year and to analyze early citation. Some recent articles are particularly influential when considering the per-year citations counts (Table 11), such as the study on strategy in emerging economies (Young, Tsai, Wang, Liu, \& Ahlstrom, 2014), the analysis of managerial ties and organizational learning by Li, Chen, Liu, and Peng (2014b), or the study on board turnover in Taiwan's public firms (Liu, Wang, Zhao, \& Ahlstrom, 2013). Initial or early citations represent some of the first (usually positive) feedback from the scientific community (Tahamtan, Afshar, \& Ahamdzadeh, 2016).

Furthermore, in the particular case of most recent articles, it is important to measure early citations as they may be a good predictor of the articles' future impact on the research field (Chakraborty, Kumar, Goyal, Ganguly, \& Mukherjee, 2014; Garner, Porter, \& Newman, 2014; Guerrero-Bote \& Moya-Anegón, 2014). Early citation counts reflect the immediacy degree of the citation process and deal with cutting-

\footnotetext{
${ }^{9}$ See, for instance Egghe (2011), Fragkiadaki, Evangelidis, Samaras, and Dervos (2011); Fragkiadaki and Evangelidis (2014).

${ }^{10}$ As shown in Schubert (2009), analyzing the SP $h$-index adds almost no value when the article receives a low number of direct (first generation) citations.
} 
Table 11 Citation analysis: Citations per year (2005-2014)

\begin{tabular}{|c|c|c|c|}
\hline Rank & Articles & Year & $\begin{array}{l}\text { Citations } \\
\text { per year }\end{array}$ \\
\hline 1 & Mathews, J. A. & 2006 & 57.40 \\
\hline 2 & Dunning, J. H., \& Lundan, S. M. & 2008 & 20.75 \\
\hline 3 & Hofstede, G. & 2007 & 17.44 \\
\hline 4 & Meyer, K. E. & 2006 & 17.20 \\
\hline 5 & Young, M. N., Tsai, T., Wang, X., Liu, S., \& Ahlstrom, D. & 2014 & 16.00 \\
\hline 6 & Li, Y., Chen, H., Liu, Y., \& Peng, M. W. & $2014 b$ & 14.00 \\
\hline 7 & Chen, Y. Y., \& Young, M. N. & 2010 & 13.83 \\
\hline 8 & Peng, M. W., \& Zhou, J. Q. & 2005 & 13.55 \\
\hline 9 & Zhu, Y., Wittmann, X., \& Peng, M. W. & 2012 & 12.50 \\
\hline 10 & Li, P. P. & 2012 & 12.00 \\
\hline 11 & Huang, Q., Davison, R. M., \& Gu, J. & 2008 & 11.13 \\
\hline $12-13$ & Estrin, S., \& Prevezer, M. & 2011 & 10.60 \\
\hline $12-13$ & Jiang, Y., \& Peng, M. W. & $2011 \mathrm{a}$ & 10.60 \\
\hline 14 & Filatotchev, I., Lien, Y.-C., \& Piesse, J. & 2005 & 9.91 \\
\hline 15 & Chu, W. & 2011 & 9.60 \\
\hline 16 & Su, Y.-S., Tsang, E. W. K., \& Peng, M. W. & 2009 & 9.43 \\
\hline 17 & Globerman, S., \& Shapiro, D. & 2009 & 8.71 \\
\hline 18 & Quer, D., Claver, E., \& Rienda, L. & 2012 & 8.50 \\
\hline 19 & Chen, V. Z., Li, J., \& Shapiro, D. M. & $2011 b$ & 8.00 \\
\hline 20 & Ahlstrom, D., Bruton, G. D., \& Yeh, K. S. & 2007 & 7.78 \\
\hline 21 & Law, K. S., Wong, C.-S., Huang, G.-H., \& Li, X. & 2008 & 7.75 \\
\hline 22 & $\begin{array}{l}\text { Heugens, P. P. M. A. R., van Essen, M., \& } \\
\text { van Oosterhout, J. (Hans) }\end{array}$ & 2009 & 7.71 \\
\hline 23 & Cui, L., \& Jiang, F. & 2010 & 7.67 \\
\hline 24 & Chen, Y., Friedman, R., Yu, E., \& Sun, F. & 2011a & 7.60 \\
\hline 25 & Yang, X., Jiang, Y., Kang, R., \& Ke, Y. & 2009 & 7.57 \\
\hline 26 & Yeung, H. W. C. & 2006 & 7.40 \\
\hline 27 & Liu, Y., Wang, L. C., Zhao, L., \& Ahlstrom, D. & 2013 & 7.33 \\
\hline 28 & Hu, H. W., Tam, O. K., \& Tan, M. G.-S. & 2010 & 7.17 \\
\hline $29-30$ & Quer, D., Claver, E., \& Rienda, L. & 2007 & 7.00 \\
\hline $29-30$ & Peng, M. W. & 2005 & 7.00 \\
\hline
\end{tabular}

Prepared by authors

edge research quickly acknowledged and cited by colleagues. This is particularly interesting in the social science fields where the publishing process is usually longer than in other disciplines (Harzing \& Van der Wal, 2008).

Table 12 includes the list of the top-30 articles published in 2013-2014 receiving more citations in the three-year period ${ }^{11}$ after their publication (working with a threeyear period allows analyzing a homogeneous time window for all of them). Apart from the above mentioned studies by Li et al. (2014a, b), Liu et al. (2013) and Young et al. (2014) among the other most promising articles there are studies related to job behavior, supervision, and job attitudes (Ngo, Loi, Foley, Zheng, \& Zhang, 2013; Wei \& Si, 2013); analyses related to family business management and succession ( $\mathrm{Au}$, Chiang, Birtch, \& Ding, 2013); works focused on knowledge management and transfer (Ling, 2013; Lunnan \& Zhao, 2014), as well as studies focusing on innovation and internationalization processes developed from an emerging economy perspective (Chen, Shapiro, \& Zhang, 2014; Meyer \& Thaijongrak, 2013).

\footnotetext{
${ }^{11}$ We are considering the year of publication and the two following ones.
} 
Table 12 Citation analysis: Early citation (2013-2014)

\begin{tabular}{|c|c|c|c|}
\hline Rank & Articles & Year & $\begin{array}{l}\text { 3-year } \\
\text { citation }\end{array}$ \\
\hline 1 & Young, M. N., Tsai, T., Wang, X., Liu, S., \& Ahlstrom, D. & 2014 & 32 \\
\hline 2 & Li, Y., Chen, H., Liu, Y., \& Peng, M. W. & $2014 b$ & 28 \\
\hline $3-4$ & Wei, F., \& Si, S. & 2013 & 13 \\
\hline $3-4$ & Au, K., Chiang, F. F. T., Birtch, T. A., \& Ding, Z. & 2013 & 13 \\
\hline 5 & Liu, Y., Wang, L. C., Zhao, L., \& Ahlstrom, D. & 2013 & 12 \\
\hline $6-8$ & Ngo, H.-Y., Loi, R., Foley, S, Zheng, X., \& Zhang, L. & 2013 & 11 \\
\hline $6-8$ & Ling, Y.-H. & 2013 & 11 \\
\hline $6-8$ & Meyer, K. E., \& Thaijongrak, O. & 2013 & 11 \\
\hline $9-11$ & Chen, V. Z., Li, J., Shapiro, D. M., \& Zhang, X. & 2014 & 9 \\
\hline $9-11$ & Lunnan, R., \& Zhao, Y. & 2014 & 9 \\
\hline $9-11$ & Zhan, W., \& Chen, R. R. & 2013 & 9 \\
\hline $12-14$ & Froese, F. J. & 2013 & 8 \\
\hline $12-14$ & Filatotchev, I., Jackson, G., \& Nakajima, C. & 2013 & 8 \\
\hline $12-14$ & Puffer, S. M., McCarthy, D. J., Jaeger, A. M., \& Dunlap, D. & 2013 & 8 \\
\hline $15-23$ & Deng, Z., Hofman, P. S., \& Newman, A. & 2013 & 7 \\
\hline $15-23$ & Ding, Z., Sun, S. L., \& Au, K. & 2014 & 7 \\
\hline $15-23$ & Lam, L. W., Loi, R., \& Leong, C. & 2013 & 7 \\
\hline $15-23$ & Sauerwald, S., \& Peng, M. W. & 2013 & 7 \\
\hline $15-23$ & Sharma, P., \& Chua, J. H. & 2013 & 7 \\
\hline $15-23$ & Wang, L., Hinrichs, K. T., Prieto, L., \& Howell, J. P. & 2013 & 7 \\
\hline $15-23$ & Wu, J., Li, S., \& Li, Z. & 2013 & 7 \\
\hline $15-23$ & Yu, B., Hao, S., Ahlstrom, D., Si, S., \& Liang, D. & 2014 & 7 \\
\hline $15-23$ & Zhu, Y., Sun, L.-Y., \& Leung, A. S. M. & 2014 & 7 \\
\hline $24-32$ & Asaba, S. & 2013 & 6 \\
\hline $24-32$ & Choi, S. B., \& Williams, C. & 2014 & 6 \\
\hline $24-32$ & Frenkel, S., Sanders, K., \& Bednall, T. & 2013 & 6 \\
\hline $24-32$ & Ismail, K. M., \& Ford, Jr., D. L., Wu, Q., \& Peng, M. W. & 2013 & 6 \\
\hline $24-32$ & Leung, K., Chen, Z., Zhou, F., \& Lim, K. & 2014 & 6 \\
\hline $24-32$ & Li, Y., Ashkanasy, N. M., \& Ahlstrom, D. & $2014 \mathrm{a}$ & 6 \\
\hline $24-32$ & Shih, C.-T., \& Chuang, C.-H. & 2013 & 6 \\
\hline $24-32$ & Stan, C. V., Peng, M. W., \& Bruton, G. D. & 2014 & 6 \\
\hline $24-32$ & Sun, W., Xu, A., \& Shang, Y. & 2014 & 6 \\
\hline
\end{tabular}

Prepared by authors

\section{Field weighted citation impact}

By considering the articles' FWCI it is possible to analyze not only the article's age or year of publication, but also its discipline or specific field of research. The FWCI indicates how the number of citations received by a publication compares with the average number of citations received by all other similar publications indexed in the Scopus database - similar publications are those publications in the Scopus database that have the same publication year, publication type (e.g., article, book chapter, etc.), and discipline. A FWCI higher/lower than 1 means that the article is more/less cited than expected, based on the average for similar publications. A second tool for contextualizing citations counts is the CB. The CB compares journal articles of the same age and subject area by providing information about the articles citation percentile (e.g., a $90 \%$ CB means that $90 \%$ of similar articles receive less citations than the analyzed work). 
Table 13 Citation analysis: Field-Weighted Citation Impact (2005-2014)

\begin{tabular}{|c|c|c|c|}
\hline Rank & Article & Year & FWCI \\
\hline 1 & Meyer, K. E. & 2006 & 52.99 \\
\hline 2 & Mathews, J. A. & 2006 & 39.4 \\
\hline 3 & Peng, M. W., \& Zhou, J. Q. & 2005 & 26.1 \\
\hline 4 & Peng, M. W. & 2005 & 22.02 \\
\hline 5 & Hofstede, G. & 2007 & 20.17 \\
\hline 6 & Bruton, G. D., Dess, G. G., \& Janney, J. J. & 2007 & 16.18 \\
\hline 7 & Ma, X., Yao, X., \& Xi, Y. & 2006 & 14.67 \\
\hline 8 & Quer, D., Claver, E., \& Rienda, L. & 2007 & 14.47 \\
\hline 9 & Young, M. N., Tsai, T., Wang, X., Liu, S., \& Ahlstrom, D. & 2014 & 13.67 \\
\hline 10 & Dunning, J. H., \& Lundan, S. M. & 2008 & 13.01 \\
\hline 11 & Yeung, H. W. C. & 2006 & 13 \\
\hline 12 & Li, Y., Chen, H., Liu, Y., \& Peng, M. W. & $2014 b$ & 11.62 \\
\hline 13 & Li, J. J. & 2005 & 11.04 \\
\hline 14 & Carney, M. & 2005 & 10.89 \\
\hline 15 & Tung, R. L. & 2005 & 10.6 \\
\hline 16 & Li, Y., Sun, Y. F., \& Liu, Y. & 2006 & 10.43 \\
\hline 17 & Hill, C. W. L. & 2007 & 10.32 \\
\hline 18 & Li, P. P. & 2012 & 9.79 \\
\hline 19 & Huang, Q., Davison, R. M., \& Gu, J. & 2008 & 9.5 \\
\hline 20 & Zhu, Y., Wittmann, X., \& Peng, M. W. & 2012 & 9.05 \\
\hline 21 & Wu, W.-P., \& Leung, A. & 2005 & 8.97 \\
\hline 22 & Law, K. S., Wong, C.-S., Huang, G.-H., \& Li, X. & 2008 & 8.71 \\
\hline $23-24$ & Bhagat, R. S., McDevitt, A. S., \& McDevitt, I. & 2010 & 8.42 \\
\hline $23-24$ & Chen, Y.,Y., \& Young, M. N. & 2010 & 8.42 \\
\hline 25 & Syed, J. & 2008 & 8.31 \\
\hline 26 & Jiang, Y., \& Peng, M. W. & 2011a & 8.24 \\
\hline 27 & Kedia, B. L., Mukherjee, D., \& Lahiri, S. & 2006 & 8.23 \\
\hline 28 & Collinson, S. \& Rugman, A. M. & 2007 & 7.89 \\
\hline 29 & Ahlstrom, D., Bruton, G. D., \& Yeh, K. S. & 2007 & 7.78 \\
\hline 30 & Estrin, S., \& Prevezer, M. & 2011 & 7.3 \\
\hline
\end{tabular}

Prepared by authors

Table 13 shows the list of the top 30 articles based on their FWC - as all of them are above the $90 \%$ CB we have not included information relative to this indicator on the table. As shown in the table, the articles showing the highest FWCI are the abovementioned works by Hofstede (2007), Mathews (2006), Meyer (2006), Peng (2005) and Peng and Zhou (2005) that were also in top positions when considering absolute citation counts. However, other articles sharply improve their performance in terms of impact when citation counts are weighted in terms of an article's age and discipline, among them the study of knowledge management in technology firms from emerging economies (Bruton, Dess, \& Janney, 2007), the analysis of the relationship between business group affiliation and firm performance in transition economies by $\mathrm{Ma}$ et al. (2006), the review of empirical research focused on business and management in China by Quer et al. (2007), and the study of the influence of emerging economies ' institutional context on local firms' strategy and competitive (dis)advantages ${ }^{12}$ (Young et al., 2014). Furthermore, some articles that received a lower number of first-generation

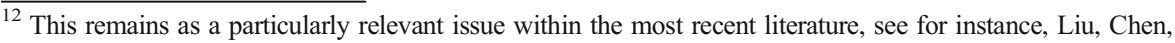
and Wang (2017).
} 
citations in absolute terms and were not included in their respective $h$-cores, arise as particularly influential when the FWCI is considered; among them, the analysis about how Asia's business networks are responding to the growing integration of the region into the global economy (Carney, 2005); the research agenda on Asian management issues put forward by Tung (2005), the study on the precedents and outcomes of market orientation in state-owned enterprises in transitional China (Li, Sun, \& Liu, 2006) and the analysis of gender equality and its implications for equal employment opportunity in Islamic societies (Syed, 2008).

\section{Impact based on alternative metrics}

Finally, we performed an analysis of article impact based on altmetrics; that is, alternative metrics for measuring scholarly impact that rely on different user activities in social media platforms and tools (Erdt, Nagarajan, Sin, \& Theng, 2016; Piwowar, 2013; Weller, 2015). In other words, altmetrics measure the interactions happening on the Internet and the social media and employ new procedures to measure the impact of authorship and publication (Ebrahimy, Mehrad, Setareh, \& Hosseinchari, 2016). They provide fast and real-time indications of impact (traditional citation processes usually require long periods of time), as well as information about the impact of scientific publications on different (including non-academic) audiences (Priem, Piwowar, \& Hemminger, 2012; Wouters \& Costas, 2012). Therefore, they measure a different kind of research impact, thus acting as a complement rather than a substitute to traditional metrics (Erdt et al., 2016). Different altmetrics exist, among them those related to saving, discussion, and recommendation. Data relative to discussion and recommendation altmetrics (e.g., tweets, "likes" in Facebook, coverage by the media or blogs) are not available for a large number of articles in our database. Therefore, we focus this analysis on saving metrics. To measure saving and download activities related to the articles gathered in our database, we have relied on Mendeley. This is a social network and reference manager that allows users to download, save, and bookmark articles. Information relative to each article of Mendeley readership activity was gathered from Scopus. Table 14 shows the top-30 articles based on this indicator. As shown in this table, the articles leading this ranking-Dunning and Lundan (2008), Estrin and Prevezer (2011), Hofstede (2007), Su, Tsang, and Peng (2009), Zhu et al. (2012) were previously included in their respective $h$-core based on traditional citation counts. Nevertheless, some recent articles not included in their h-core emerge as highly influential when considering this altmetrics indicator, among them, the study of the impact of transformational leadership on technological innovation by Chen, Lin, Lin, and McDonough (2012), the analysis relative to the dynamics of emerging economy MNEs (Meyer \& Thaijongrak, 2013); the study relative to the influence of different leadership types on team performance (Ishikawa, 2012), and two studies related to small firm performance (Jing, Avery, \& Bergsteiner, 2014; Tang \& Tang, 2012).

\section{Analysis and discussion}

This research represents a comprehensive review of the literature published in APJM between 2005 and 2014, during the journal's “early adulthood." Throughout this decade, 
Table 14 Articles impact based on almetrics (2005-2014)

\begin{tabular}{|c|c|c|c|}
\hline Rank & Article & Year & $\begin{array}{l}\text { Mendeley } \\
\text { readers }\end{array}$ \\
\hline 1 & Dunning, J. H., \& Lundan, S. M. & 2008 & 298 \\
\hline 2 & Estrin, S., \& Prevezer, M. & 2011 & 226 \\
\hline 3 & Hofstede, G. & 2007 & 179 \\
\hline 4 & Zhu, Y., Wittmann, X., \& Peng, M. W. & 2012 & 150 \\
\hline 5 & Su, Y.-S., \& Tsang, E. W. K., \& Peng, M. W. & 2009 & 136 \\
\hline 6 & Chen, M. Y.-C., Lin, C. Y.-Y., Lin, H.-E., \& McDonough, III, E. F. & 2012 & 120 \\
\hline 7 & Meyer, K. E., \& Thaijongrak, O. & 2013 & 105 \\
\hline 8 & Chu, W. & 2011 & 104 \\
\hline $9-10$ & Law, K. S., Wong, C.-S., Huang, G.-H., \& Li, X. & 2008 & 93 \\
\hline $9-10$ & van Essen, M., van Oosterhout, J. (Hans), \& Carney, M. & 2012 & 93 \\
\hline 11 & Li, J., \& Kozhikode, R. K. & 2008 & 92 \\
\hline 12 & Huang, Q., Davison, R. M., \& Gu, J. & 2008 & 91 \\
\hline 13 & Ishikawa, J. & 2012 & 90 \\
\hline 14 & Cuervo-Cazurra, A. & 2006 & 87 \\
\hline 15 & Peng, M. W., \& Zhou, J. Q. & 2005 & 86 \\
\hline 16 & Tang, Z., \& Tang, J. & 2012 & 84 \\
\hline $17-19$ & Meyer, K. E. & 2006 & 82 \\
\hline $17-19$ & Gao, X., Xu, K., \& Yang, J. & 2008 & 82 \\
\hline $17-19$ & Jing, F. F., Avery, G. C., \& Bergsteiner, H. & 2014 & 82 \\
\hline $20-21$ & Lin, J., \& Si, S. X. & 2010 & 81 \\
\hline $20-21$ & Dodgson, M. & 2009 & 81 \\
\hline $22-24$ & Hill, C. W. L. & 2007 & 80 \\
\hline $22-24$ & Li, Y., Chen, H., Liu, Y., \& Peng, M. W. & $2014 b$ & 80 \\
\hline $22-24$ & Tang, J. & 2010 & 80 \\
\hline 25 & Quer, D., Claver, E., \& Rienda, L. & 2012 & 78 \\
\hline $26-29$ & Li, P. P. & 2007 & 77 \\
\hline $26-29$ & Ling, Y.-H. & 2013 & 77 \\
\hline $26-29$ & Zhan, W., \& Chen, R. R. & 2013 & 77 \\
\hline $26-29$ & Zheng, C., \& Lamond, D. & 2010 & 77 \\
\hline 30 & Wei, F., \& Si, S. & 2013 & 75 \\
\hline
\end{tabular}

Prepared by authors

APJM has achieved some key objectives established by its editorial board at the beginning of the period, among them, improving the journal's "numbers," quality, reputation, and influence (Ahlstrom, 2010; Delios, 2005). Although measuring journal quality and reputation is a complex task, several indicators can be analyzed, among them, a journal's reach and international scope, its performance in terms of journal metrics, the funding support to the research published in the journal, cooperative research patterns, and the published articles' impact on the research and professional field.

\section{APJM numbers and reach}

The number of articles published per year has sharply increased from a mean of 25 articles in the first 4 years of this century to a mean of 36 articles in the analyzed period (about 9 articles per issue) and to 45 articles (more than 11 articles per issue) if we focus on the 2010-2014 period, after the journal attained SSCI coverage. Among these are research articles dealing with conceptual developments and empirical tests (319 articles), literature reviews that map a field and reflect on its research agenda (17), and 
perspectives relative to a specific theme developed by leaders in their respective research fields (27). The "perspectives" and "reviews" sections deserve special attention as they were created by the editorial board at the beginning of the analyzed period to enhance the journal's visibility (Delios, 2005). These two sections include articles written "by established and up-and-coming scholars, with perspective pieces being more speculative and forward-looking and review articles being solid literature reviews" (Peng, 2007b: 5).

The first Perspectives articles were published by the journal in 2006. Since them, APJM has been able to attract a wide range of top authors such as Geert Hofstede, Mike W. Peng, and Robert Liden, just to name a few, that have reflected on an extensive list of key topics relevant to the AP region. Furthermore, some of these articles have had a strong impact on their research fields (in terms of total citation, FWCI, and/or early citation); among them, the reflections by Ahlstrom, Bruton, and Yeh (2007) on venture capital in China; Asakawa and Som (2008) on internationalization of R\&D in China and India; Bhagat et al. (2010) on improving the robustness of Asian management theories; Bruton et al. (2007) on knowledge management in technology-focused firms in emerging economies; Hill (2007) on digital piracy; Li (2012) on indigenous research; Liden (2012) on leadership research in Asia; Yeung (2006) on ethnic Chinese business, and Young et al. (2014) on strategy in emerging economies.

The Reviews section was more prolific in the 2005-2009 period; furthermore, some of the reviews published by APJM in this period are among the most cited articles in absolute terms and/or among the articles showing the strongest impact on their respective fields: the review by Mathews (2006) on the role of dragon multinationals in the global arena; the one by Meyer (2006) relative to Asian management research and its need for confidence; the article by Kedia, Mukherjee, and Lahiri (2006) about Indian business groups; the review by Li (2007) about the role of social ties, social capital, and social behavior in informal exchanges; and the article by Quer et al. (2007) on business and management in China.

The weight of both perspectives and reviews has decreased during the second subperiod. Different factors may underlie this decrease - among them, the increasing number of regular papers and the higher visibility already achieved by the journal as well as a near tripling of submissions during that latter period. However, it is noteworthy that the volume of reviews and perspectives that are included among the most influential articles is higher than expected considering their weight on the total number of articles. Therefore, these two sections have consistently contributed to boosting the journal's visibility and impact and it may be expected that they will contribute further in the future.

Regardless of the increase in the number of regular articles, there is a clear predominance of empirical articles based on quantitative methods like that shown in previous stages and some lack of both conceptual articles and empirical papers based on qualitative methods different from case studies. Research developed from a qualitative perspective(e.g., qualitative comparative, ethnographic, longitudinal qualitative, or phenomenological studies) can make substantial contributions to a research field (Doz, 2011). This type of research is suited not only to exploration, discovery, induction, and theory building, but also to theory-testing and confirmation (Welch et al., 2013). Increasing the volume of conceptual works and empirical-qualitative articles remains a longstanding pending assignment. Actually, the interest of publishing 
articles that move theoretical conceptualization forward was already pointed out by Pleggenkuhle-Miles et al. in their 2007 review. Furthermore, this is a trend already shown by other top-tier management journals (Welch et al., 2013); it seems that assumptions/expectations relative to dominant methodological conventions and requirements involved in the review and publishing processes make it difficult for scholars to publish conceptual or qualitative research in this kind of journals. In Peng's (2009b) words, there is an increasing number of articles focused almost exclusively on exploitation at the expense of exploration. In short, it seems that the need for thorough conceptual developments already raised by Lau (2002b), is still in force.

\section{Stepping back}

Over 660 authors and 330 institutions contributed to APJM over the analyzed decade. Both the number of scholars and the volume of institutions are much higher than in the journal's childhood (Ang, 1997) and adolescence (Pleggenkuhle-Miles et al., 2007). Moreover, when traditional bibliometric laws are used to analyze these data, results point to a particularly high number of scholars/institutions (higher than would commonly be expected) publishing their work in APJM. In addition, the international scope of authorship has also increased, which can be understood both as a cause and a consequence of the journal's international reputation. The increase in the volume and international scope of institutional authorship is tightly related to the extensive work undertaken to globalize APJM's editorship — see discussions by recent APJM Chief Editors Mike Peng (2007b, 2008), David Ahlstrom (2010), and Michael Carney (2013, 2014).

In short, it is quite clear that "the numbers" of the journal have improved considerably over this recent 10-year period and the journal has extended its reach in terms of scholars and institutions coming together in a growing research community on management in Asia. Furthermore, the number of submission rose from about 100 per year in 2005 to 450 in 2010 and 800 in 2014 (see Carney, 2015). Such a high increase points to a wider range of scholars considering the $A J P M$ as an appropriate outlet for publishing their research; in other words, the journal's assessment by the research community improved very noticeably throughout the decade. The rise in the number of published articles in the analyzed period is much lower than the rise in the number of submissions. This means a decrease in the acceptance rate, which fell to about $5 \%$ in 2014. ${ }^{13}$ As shown in Carney (2015), this rate is similar to that shown by the best ranked journals in the management and international business areas and points to increasingly rigorous and demanding review processes.

APJM published ten Special Issues in the analyzed decade involving a total of 106 articles. Publishing Special Issues that bundle together a collection of articles on a topic of high relevance to the AP region was a deliberate strategy of the journal's editorial board aimed at increasing the journal's reach and reputation-see Delios (2005). Usually these Special Issues provide opportunities for analyzing state of the art research on a specific theme, improving our understanding about it, bringing together scholars from diverse areas, and explaining theoretical advances and empirical tests. Furthermore, each article in a Special Issue increases its exposure to the research community

\footnotetext{
${ }^{13}$ Information about yearly evolution of submission and acceptance rates can be found in editorials by Ahlstrom (2010, 2011), Carney (2013), and Peng (2007b, 2008).
} 
and its impact on it due to the high synergy within the issue (Olk \& Griffith 2004). Up to $36 \%$ of the articles included in the journal's $h$-cores were published in Special Issues (it rises to $40 \%$ for the 2005-2009 period). These are percentages which are higher than expected when we consider the weight of Special-Issue-articles on the total amount of articles published by APJM. More than one-third of the articles included in the top-30 articles in terms of FWCI were published in Special Issues, confirming the role of these special volumes in expanding the journal's visibility and impact. Special Issues published in the first sub-period have achieved a particularly high impact on the research field (in terms of citation and FWCI), among them, the Special Issues on networks in AP business (2005), conglomerates and business groups in the AP region (2006), knowledge management and innovation strategy, as well as the volume dedicated to the 25th Anniversary of the journal. Among the most recent Special Issues, the most influential volumes are the one focused on management issues in ethnic Chinese communities (Ahlstrom, Chen, \& Yeh, 2010) and the one dealing with managing corporate governance in Asia (Globerman, Peng, \& Shapiro, 2011). In short, these Special Issues positively impacted knowledge development (Olk and Griffith, 2004), as well as the journal's performance and metrics.

\section{Journal performance based on journal metrics}

As previously stated, journal metrics provide an assessment of a journal's performance in terms of quality and prestige (Glänzel \& Moed, 2002). APJM got its first SJR and JCR impact factors in 1999 and 2010 respectively. It sharply improved its performance based on the SJR indicator and it kept its ranking above the SJR index first quartile over the whole analyzed period in different categories-Business and International Management, Strategy and Management, Economics, and Econometrics and Finance. In 2008 the journal got to be selected for WOS-SSCI coverage (Peng, 2009a), getting its first JCR impact factor in 2010. It achieved a ranking above the JCR's first quartile (Management category) in 2010 and it kept this position until the end of the analyzed period. These metrics confirm that APJM has consolidated itself as a leading international business journal: based on these metrics, APJM is ranked among the top management journals worldwide and is the first among all management journals with a declared regional focus.

Actually getting to be listed in the SSCI was the most relevant challenge facing APJM's editorial board at the beginning of the analyzed period-see Delios (2005) and Peng (2007b). Many factors are considered when evaluating journals for SSCI coverage, among them: The application of some basic publishing standards (e.g., peer-review process, ethical publishing practices, timeliness of publication, etc.), the editorial contents, the journal's international focus, and the citation analysis both in terms of total citation counts and impact factors that focus on the recent effect of the journal on the literature of its subject. Some of these issues heavily depend on the editorial board; therefore, an explicit recognition should be given to the different members of the board and Editorsin-Chief during the analyzed decade-Andrew Delios (National University of Singapore) was the Editor-in-Chief from 2004 to 2006, Mike W. Peng (the University of Texas at Dallas, US) in 2007-2009, David Ahlstrom (The Chinese University of Hong Kong) in 2010-2012, and Michael (Mick) Carney (Concordia 
University, Canada) in 2013-2015. When dealing with citation counts and recent impact factors, the articles published in the 2005-2009 period played a key role as promoters of the journal's selection for SSCI coverage, particularly, those achieving the highest citation counts and included in the 2005-2009 APJM's h-core. Furthermore, some of these articles show a high Single-Publication- $h$-index based on second generation citations, pointing to central articles in the research field (Schubert, 2009) — we will now refer to the specific articles contributing the most to this recognition.

\section{Scientific collaboration and funding-support}

When compared to individual researchers, research networks facilitate facing bigger challenges and studying more complex problems and environments (Beaver, 2001). APJM publication pattern has consistently evolved towards collaborative research. Our analysis points to a relevant and steady increase in collaborative research not only when compared to previous stages, but also when comparing different sub-periods within the analyzed decade. Furthermore, our study shows that large international teams play a key role in the research published in APJM. Therefore, it seems that collaboration among scholars and participation in large cross-national networks are tools that help to achieve the increasing standards of conceptual and methodological rigor required by APJM. However, collaborative patterns are limited to collaboration ties and networks among academic institutions, as active collaboration between academic institutions and firms or governmental agencies is extremely scarce. This low number of non-academic institutions involved in article authorship points to weak cooperation ties among different actors in the triple helix model of universityindustry-government relations (Leydesdorff \& Meyer, 2003). In other words, firms and non-academic institutions do not collaborate with academic institutions in scientific research in a way that gives rise to co-authored works.

About one-third of the articles published by APJM in this period deals with funded research projects and/or grants. Data relative to funding patterns in previous stages are not available; anyhow, we have found a significant increase of funding-supported articles in the second sub-period. External support to research projects means that both the issue under research and the research team in charge of it have received external recognition (in terms of funding). Therefore, it can be regarded as an additional sign of the relevance and quality of the research project and the published article. In addition, it creates a wider context for the piece of research and the journal.

Quite surprisingly, we have not found a statistically significant correlation between article impact or visibility and collaborative research or external support. It seems that participating in larger or international teams, cooperating with non-academic institutions or getting financial support influence neither the articles' impact on the research field (in terms of citation counts) nor their visibility (in terms of Mendeley readers). This is an unexpected result, as articles pieced together through collaborative research and international research networks and funding-supported pieces of research are usually more influential in their research fields - see Tahamtan et al. (2016) for an extensive review. 


\section{International scope of article content and authorship}

First, in terms of article content, the journal has increased its international scope and reach, which is a particularly relevant issue given the increasingly global scope of management research and the integration of regional studies in the management field into a comprehensive theoretical literature (Delios, 2005). Up to 25\% of the articles published by the journal over this decade deal with general (e.g., not country-focused) management and organizational issues or with these kinds of issues in a bilateral or multilateral international context. Getting to publish articles that foster new insights, raise questions which are pertinent worldwide, and focus on themes of interest to global management researchers was (and still is) a big challenge faced by APJM, as recognized early on by Bartunek (2002) and Lau (2002a).

Among the articles focused on just one country, there is no doubt that China has attracted the attention of a wide range of scholars (most of them interested in its role as an international economic player) - the percentage of articles focused on this nation has increased throughout the decade, as has the volume of articles focused on Japan, South Korea, and India. Nevertheless, a significant number of articles focuses on different nations, among them, countries that were not considered by authors in previous stages (e.g., Iran, Pakistan, Philippines, Russia), pointing to a more Asia-wide focus than in previous years. Widening the journal's geographical focus to cover the whole AP region (encompassing the Pacific Rim countries and mainland Asia) has been an editorial endeavor during the analyzed decade, as shown in Ahlstrom (2010).

In addition, there is a strong internationalization of the journal's authorship, as scholars are affiliated to institutions located in more than 30 different countries. As was previously mentioned, there is a majority of articles developed by international research networks. Most of them reflect inter-regional cooperation, that is, research networks whose authors' institutional affiliation includes different regions. This is a distinctive and valuable feature of the literature published in APJM-recent studies have focused on the international business field (López-Duarte, Vidal-Suárez, González-Díaz, \& Rosa-Reis, 2016) and multi-field studies (Fernández et al., 2016; Hoekman, Frenken, \& Tijssen, 2010) show a much lower ratio of inter-regional scientific collaboration.

\section{Impact of published articles}

As pointed out by Peng (2009a), a journal is only as good as its authors (and articles). To measure the actual impact of each article published in the journal we performed a citation study (based on direct, indirect, weighted, and early citation counts) and an altmetrics analysis. A citation of a work means that it has been used and recognized as relevant by the citing scholar and that the cited work is somehow related in content to the citing one (Glänzel \& Schoepflin, 1999). In other words, citation counts measure influence (Starbuck, 1994). To take into account the articles age and specific discipline, we relied on absolute citation counts (splitting the database into two different subperiods), per-year citation counts, early citation, and field-weighted citation impacts.

Based on absolute citation counts we identified the set of articles included in APJM's $h$-core in 2005-2009 and in 2010-2014. The 2005-2009 h-core gathers together 37 articles (more than $25 \%$ of the total number of articles published by the journal in this 
period), while the 2010-2014 one includes 24 articles (about $10 \%$ of the total number of articles) - obviously, the number of articles included in the most recent $h$-core is lower, as the articles published in this period had a shorter period of time to be cited. Among them, the above-mentioned reviews and perspectives, as well as research articles published in Special Issues or regular ones, among them some conceptual developments (e.g., Dunning \& Lundan, 2008; Estrin \& Prevezer, 2011; Hofstede, 2007; Peng \& Zhou, 2005) and empirical tests based on quantitative methodologies (among them, Chen \& Young, 2010; Filatochev et al., 2005; Jiang \& Peng, 2011a; Zhu et al., 2012). In order to measure the indirect impact of highly cited articles, as well as their centrality, we analyzed their Single Publication $h$-index based on second generation citations (Schubert, 2009). Some articles increase their influence on the field when considering this accumulated impact (e.g., Li, 2005; Ma et al., 2006; Quer et al., 2007). Analyzing citation per year and early citation allows the identification of articles that have been recently published and show a high expected impact (e.g., Li et al., 2014a, b; Ooi, Cheah, Lin, \& Teh, 2012; Young et al., 2014).

More than $75 \%$ of the articles published by APJM over the decade show a FWCI higher than 1-this percentage rises to almost 90\% in 2005-2009-therefore, these articles have been cited more than would be expected based on the average for similar publications (e.g., same year, discipline and type of article). Furthermore, up to $50 \%$ of the articles show a FWCI higher than 2, which means they have been cited as much as twice as expected (or more). The CB is over $90 \%$ for about one-third of the articles (once again, the percentage is higher in the first sub-period than in the second one). Therefore, this set of articles are among the $10 \%$ most cited works in their year/subject area. Furthermore, 22 articles (6\% of the total) show a 99\% CB being included among the $1 \%$ most influential articles (in terms of citations) in their respective year/discipline (more than half of them published between 2010 and 2014).

All of these data point to a sharp increase in citation counts when compared to previous stages (Pleggenkuhle-Miles et al., 2007). APJM has come a long way since the "modest but promising" citation numbers analyzed by Delios in his 2005 editorial. All of these data demonstrate the increased prestige of APJM throughout recent years and among the academic community.

As a complement to the citation analysis, we performed a study based on altmetrics, as these indicators provide faster indications of impact and information about the impact of articles on wider audiences (including non-academic ones). This analysis has allowed us to identify some articles recently published by APJM that show a high impact based on social media interactions (e.g., Chen et al., 2012; Ishikawa, 2012; Jing et al., 2014; Meyer \& Thaijongrak, 2013; Tang \& Tang, 2012). It would have been interesting to perform analysis based on additional altmetrics indexes (posts on social media platforms, mass media); however, an extremely low percentage of the articles in the database showed activity related to these alternative indexes.

All in all, APJM's early adulthood is featured by rapid and positive changes in terms of numbers, reach, international scope, scientific collaboration, article impact, and journal's performance. Some key challenges remain (e.g., increasing the volume of conceptual and theory-building works and non-quantitative or case-based empirical articles) and new research foci are arising such as increasing demands for entrepreneurship and small business research (e.g., Guo, Su, \& Ahlstrom, 2016), family business (Liu et al., 2017), emotion (Li, 2011; Peng, 2017), history and management 
(Ahlstrom, Lamond, \& Ding, 2009), and work beyond East Asia (e.g., Bruton, Ahlstrom, \& Si, 2015; Nair, Guldiken, Fainshmidt, \& Pezeshkan, 2015). In doing so, $A P J M$ can continue to keep the journal's performance ratings up, while continuing to attract fine contributors (and reviewers), while positioning the journal among the best management journals contributing to the important research on emerging Asia.

\section{References}

Acedo, F. J., \& Casillas, J. C. 2005. Current paradigms in the international management field: An author cocitation analysis. International Business Review, 14: 619-639.

Adams, J. D., Black, G. C., Clemmons, J. R., \& Stephan, P. E. 2005. Scientific teams and institutional collaborations: Evidence from US universities, 1981-1999. Research Policy, 34(3): 259-285.

Ahlstrom, D. 2010. Publishing in the Asia Pacific Journal of Management. Asia Pacific Journal of Management, 27(1): 1-8.

Ahlstrom, D. 2011. On the aims and scope of the Asia Pacific Journal of Management: What does APJM really seek to publish?. Asia Pacific Journal of Management, 28(2): 215-219.

Ahlstrom, D., Bruton, G. D., \& Yeh, K. S. 2007. Venture capital in China: Past, present, and future. Asia Pacific Journal of Management, 24(3): 247-268.

Ahlstrom, D., Chen, S. J., \& Yeh, K. S. 2010. Managing in ethnic Chinese communities: Culture, institutions, and context. Asia Pacific Journal of Management, 27(3): 341-354.

Ahlstrom, D., Lamond, D., \& Ding, Z. 2009. Reexamining some management lessons from military history. Asia Pacific Journal of Management, 26(4): 617-642.

Ahn, M. J., \& York, A. S. 2011. Resource-based and institution-based approaches to biotechnology industry development in Malaysia. Asia Pacific Journal of Management, 28(2): 257-275.

Ang, S. H. 1997. Fourteen years of research in the Asia Pacific Journal of Management. Asia Pacific Journal of Management, 14(1): 89-97.

Asaba, S. 2013. Patient investment of family firms in the Japanese electric machinery industry. Asia Pacific Journal of Management, 30(3): 697-715.

Asakawa, K., \& Som, A. 2008. Internationalization of R\&D in China and India: Conventional wisdom versus reality. Asia Pacific Journal of Management, 25(3): 375-394.

Au, K., Chiang, F. F. T., Birtch, T. A., \& Ding, Z. 2013. Incubating the next generation to venture: The case of a family business in Hong Kong. Asia Pacific Journal of Management, 30(3): 749-767.

Bartunek, J. M. 2002. Congratulations to the Asia Academy of Management on this new venture. Asia Pacific Journal of Management, 19(1): 9.

Beaver, D. D. 2001. Reflections on scientific collaboration (and its study): Past, present, and future. Scientometrics, 52(3): 365-377.

Beaver, D. D. 2004. Does collaborative research have greater epistemic authority?. Scientometrics, 60(3): 399-408.

Bhagat, R. S., McDevitt, A. S., \& McDevitt, I. 2010. On improving the robustness of asian management theories: Theoretical anchors in the era of globalization. Asia Pacific Journal of Management, 27(2): 179192.

Bornmann, L., Mutz, R., Hug, S. E., \& Daniel, H. D. 2011. A multilevel meta-analysis of studies reporting correlations between the $h$ index and 37 different $h$ index variants. Journal of Informetrics, 5(3): 346-359.

Bruton, G. D., Ahlstrom, D., \& Si, S. 2015. Entrepreneurship, poverty, and Asia: Moving beyond subsistence entrepreneurship. Asia Pacific Journal of Management, 32(1): 1-22.

Bruton, G. D., Dess, G. G., \& Janney, J. J. 2007. Knowledge management in technology-focused firms in emerging economies: Caveats on capabilities, networks, and real options. Asia Pacific Journal of Management, 24(2): 115-130.

Carney, M. 2005. Globalization and the renewal of Asian business networks. Asia Pacific Journal of Management, 22(4): 337-354.

Carney, M. 2013. Growth and continuity at APJM. Asia Pacific Journal of Management, 30(1): 1-5.

Carney, M. 2014. From the editor's desk. Asia Pacific Journal of Management, 31(3): 661-664.

Carney, M. 2015. Capacity building at the Asia Pacific Journal of Management. Asia Pacific Journal of Management, 32(4): 827-833. 
Chakraborty, T., Kumar, S., Goyal, P., Ganguly, N., \& Mukherjee, A. 2014. Towards a stratified learning approach to predict future citation counts. Paper presented at the Proceedings of the ACM/IEEE joint conference on digital libraries.

Chen, C. C., \& Chen, X.-P. 2009. Negative externalities of close guanxi within organizations. Asia Pacific Journal of Management, 26(1): 37-53.

Chen, M. Y.-C., Lin, C. Y.-Y., Lin, H.-E., \& McDonough, III, E. F. 2012. Does transformational leadership facilitate technological innovation? The moderating roles of innovative culture and incentive compensation. Asia Pacific Journal of Management, 29(2): 239-264.

Chen, N. Y.-F., \& Tjosvold, D. 2007. Guanxi and leader member relationships between American managers and Chinese employees: Open-minded dialogue as mediator. Asia Pacific Journal of Management, 24(2): 171-189.

Chen, V. Z., Li, J., \& Shapiro, D. M. 2011b. Are OECD-prescribed "good corporate governance practices" really good in an emerging economy?. Asia Pacific Journal of Management, 28(1): 115-138.

Chen, V. Z., Li, J., Shapiro, D. M., \& Zhang, X. 2014. Ownership structure and innovation: An emerging market perspective. Asia Pacific Journal of Management, 31(1): 1-24.

Chen, Y. Y., \& Young, M. N. 2010. Cross-border mergers and acquisitions by Chinese listed companies: A principal-principal perspective. Asia Pacific Journal of Management, 27(3): 523-539.

Chen, Y., Friedman, R., Yu, E., \& Sun, F. 2011a. Examining the positive and negative effects of guanxi practices: A multi-level analysis of guanxi practices and procedural justice perceptions. Asia Pacific Journal of Management, 28(4): 715-735.

Choi, S. B., \& Williams, C. 2014. The impact of innovation intensity, scope, and spillovers on sales growth in Chinese firms. Asia Pacific Journal of Management, 31(1): 25-46.

Chu, W. 2011. Family ownership and firm performance: Influence of family management, family control, and firm size. Asia Pacific Journal of Management, 28(4): 833-851.

Collinson, S., \& Rugman, A. M. 2007. The regional character of Asian multinational enterprises. Asia Pacific Journal of Management, 24(4): 429-446.

Cuervo-Cazurra, A. 2006. Business groups and their types. Asia Pacific Journal of Management, 23(4): 419437.

Cui, L., \& Jiang, F. 2010. Behind ownership decision of Chinese outward FDI: Resources and institutions. Asia Pacific Journal of Management, 27(4): 751-774.

Delios, A. 2005. Editorial-The APJM since January 2004: On the move. Asia Pacific Journal of Management, 22(2): 115-121.

Deng, Z., Hofman, P. S., \& Newman, A. 2013. Ownership concentration and product innovation in Chinese private SMEs. Asia Pacific Journal of Management, 30(3): 717-734.

Ding, Z., Sun, S. L., \& Au, K. 2014. Angel investors' selection criteria: A comparative institutional perspective. Asia Pacific Journal of Management, 31(3): 705-731.

Dodgson, M. 2009. Asia's national innovation systems: Institutional adaptability and rigidity in the face of global innovation challenges. Asia Pacific Journal of Management, 26(3): 589-609.

Doz, Y. 2011. Qualitative research for international business. Journal of International Business Studies, 42: $582-590$.

Dunning, J. H., \& Lundan, S. M. 2008. Institutions and the OLI paradigm of the multinational enterprise. Asia Pacific Journal of Management, 25(4): 573-593.

Ebadi, A., \& Schiffauerova, A. 2016. How to boost scientific production? A statistical analysis of research funding and other influencing factors. Scientometrics, 106(3): 1093-1116.

Ebrahimy, S., Mehrad, J., Setareh, F., \& Hosseinchari, M. 2016. Path analysis of the relationship between visibility and citation: the mediating roles of save, discussion, and recommendation metrics. Scientometrics, 109: 1497-1510.

Egghe, L. 2011. The single publication $H$-index of papers in the Hirsch-core of a researcher and the indirect $H$ index. Scientometrics, 89: 727-739.

Erdt, M., Nagarajan, A., Sin, S.-C. J., \& Theng, Y. L. 2016. Altmetrics: An analysis of the state-of-the-art in measuring research impact on social media. Scientometrics, 109: 1117-1166.

Estrin, S., \& Prevezer, M. 2011. The role of informal institutions in corporate governance: Brazil, Russia, India, and China compared. Asia Pacific Journal of Management, 28(1): 41-67.

Fernández, A., Ferrándiz, E., \& León, M. D. 2016. Proximity dimensions and scientific collaboration among academic institutions in Europe: The closer, the better?. Scientometrics, 106(3): 1073-1092.

Filatotchev, I., Jackson, G., \& Nakajima, C. 2013. Corporate governance and national institutions: A review and emerging research agenda. Asia Pacific Journal of Management, 30(4): 965-986.

Filatotchev, I., Lien, Y.-C., \& Piesse, J. 2005. Corporate governance and performance in publicly listed, family-controlled firms: Evidence from Taiwan. Asia Pacific Journal of Management, 22(3): 257-283. 
Fragkiadaki, E., \& Evangelidis, G. 2014. Review of the indirect citations paradigm: Theory and practice of the assessment of papers, authors and journals. Scientometrics, 99: 261-288.

Fragkiadaki, E., \& Evangelidis, G. 2016. Three novel indirect indicators for the assessment of papers and authors based on generations of citations. Scientometrics, 106: 657-694.

Fragkiadaki, E., Evangelidis, G., Samaras, N., \& Dervos, D. A. 2011. F-Value: measuring an article’s scientific impact. Scientometrics, 86: 671-686.

Frenkel, S., Sanders, K., \& Bednall, T. 2013. Employee perceptions of management relations as influences on job satisfaction and quit intentions. Asia Pacific Journal of Management, 30(1): 7-29.

Froese, F. J. 2013. Work values of the next generation of business leaders in Shanghai, Tokyo, and Seoul. Asia Pacific Journal of Management, 30(1): 297-315.

Gao, S., Xu, K., \& Yang, J. 2008. Managerial ties, absorptive capacity, and innovation. Asia Pacific Journal of Management, 25(3): 395-412.

Garner, J., Porter, A. L., \& Newman, N. C. 2014. Distance and velocity measures: Using citations to determine breadth and speed of research impact. Scientometrics, 100(3): 687-703.

Glänzel, W. 2001. National characteristics in international scientific co-authorship. Scientometrics, 51(1): 69115.

Glänzel, W., \& Moed, H. F. 2002. Journal impact measures in bibliometric research. Scientometrics, 53(2): $171-193$.

Glänzel, W., \& Schoepflin, U. 1999. A bibliometric study of reference literature in the sciences and social sciences. Information Processing and Management, 35: 31-44.

Glänzel, W., \& Schubert, A. 1985. Price distribution. An exact formulation of price's square root law. Scientometrics, 7(3): 211-219.

Globerman, S., \& Shapiro, D. 2009. Economic and strategic considerations surrounding Chinese FDI in the United States. Asia Pacific Journal of Management, 26(1): 163-183.

Globerman, S., Peng, M. W., \& Shapiro, D. 2011. Corporate governance and Asian companies. Asia Pacific Journal of Management, 28(1): 1-14.

Gong, Y., Chow, I. H., \& Ahlstrom, D. 2011. Cultural diversity in China: Dialect, job embeddedness, and turnover. Asia Pacific Journal of Management, 28(2): 221-238.

Guerrero-Bote, V. P., \& Moya-Anegón, F. 2014. Relationship between downloads and citations at journal and paper levels, and the influence of language. Scientometrics, 101(2): 1043-1065.

Guo, H., Su, Z., \& Ahlstrom, D. 2016. Business model innovation: The effects of exploratory orientation, opportunity recognition, and entrepreneurial bricolage in an emerging economy. Asia Pacific Journal of Management, 33(2): 533-549.

Harzing, A. W., \& Alakangas, S. 2016. Google Scholar, Scopus and the Web of Science: A longitudinal and cross-disciplinary comparison. Scientometrics, 106(2): 787-804.

Harzing, A. W., \& van der Wal, R. 2008. Google Scholar as a new source for citation analysis. Ethics in Science and Environmental Politics, 8: 61-63.

He, Y., Tian, Z., \& Chen, Y. 2007. Performance implications of nonmarket strategy in China. Asia Pacific Journal of Management, 24(2): 151-169.

Heugens, P. P. M. A. R., van Essen, M., \& van Oosterhout, J. (Hans). 2009. Meta-analyzing ownership concentration and firm performance in Asia: Towards a more fine-grained understanding. Asia Pacific Journal of Management, 26(3): 481-512.

Hill, C. W. L. 2007. Digital piracy: Causes, consequences, and strategic responses. Asia Pacific Journal of Management, 24(1): 9-25.

Hirsch, J. E. 2005. An index to quantify an individual's scientific research output. Proceedings of the National Academy of Sciences of the United States of America, 102(46): 16569-16572.

Hoekman, J., Frenken, K., \& Tijssen, R. J. W. 2010. Research collaboration at a distance: Changing spatial patterns of scientific collaboration within Europe. Research Policy, 39: 662-673.

Hofstede, G. 2007. Asian management in the $21^{\text {st }}$ century. Asia Pacific Journal of Management, 24(4): 411420.

Hu, H. W., Tam, O. K., \& Tan, M. G.-S. 2010. Internal governance mechanisms and firm performance in China. Asia Pacific Journal of Management, 27(4): 727-749.

Huang, Q., Davison, R. M., \& Gu, J. 2008. Impact of personal and cultural factors on knowledge sharing in China. Asia Pacific Journal of Management, 25(3): 451-471.

Huang, X., Shi, K., Zhang, Z., \& Cheung, Y. L. 2006. The impact of participative leadership behavior on psychological empowerment and organizational commitment in Chinese state-owned enterprises: The moderating role of organizational tenure. Asia Pacific Journal of Management, 23(3): 345-367. 
Ishikawa, J. 2012. Transformational leadership and gatekeeping leadership: The roles of norm for maintaining consensus and shared leadership in team performance. Asia Pacific Journal of Management, 29(2): 265283.

Ismail, K. M., \& Ford, D. L. 2010. Organizational leadership in Central Asia and the Caucasus: Research considerations and directions. Asia Pacific Journal of Management, 27(2): 321-340.

Ismail, K. M., Ford, Jr., D. L., Wu, Q., \& Peng, M. W. 2013. Managerial ties, strategic initiatives, and firm performance in central Asia and the Caucasus. Asia Pacific Journal of Management, 30(2): 433-446.

Jain, S., Nair, A., \& Ahlstrom, D. 2015. Introduction to the Special Issue: Towards a theoretical understanding of innovation and entrepreneurship in India. Asia Pacific Journal of Management, 32(4): 835-841.

Jiang, Y., \& Peng, M. W. 2011a. Are family ownership and control in large firms good, bad, or irrelevant?. Asia Pacific Journal of Management, 28(1): 15-39.

Jiang, Y., \& Peng, M. W. 2011b. Principal-principal conflicts during crisis. Asia Pacific Journal of Management, 28(4): 683-695.

Jing, F. F., Avery, G. C., \& Bergsteiner, H. 2014. Enhancing performance in small professional firms through vision communication and sharing. Asia Pacific Journal of Management, 31(2): 599-620.

Kedia, B. L., Mukherjee, D., \& Lahiri, S. 2006. Indian business groups: Evolution and transformation. Asia Pacific Journal of Management, 23(4): 559-577.

Knight, G. A., Hult, G. T. M., \& Bashaw, R. E. 2000. Research productivity in the Journal of Business Research: 1985-1999. Journal of Business Research, 49(3): 313-314.

Kochen, M. 1987. How well do we acknowledge intellectual debts?. Journal of Documentation, 43(1): 54-64.

Kumar, V., \& Kundu, S. 2004. Ranking the international business schools: Faculty publication as the measure. Management International Review, 44: 213-228.

Lam, L. W., Loi, R., \& Leong, C. 2013. Reliance and disclosure: How supervisory justice affects trust in supervisor and extra-role performance. Asia Pacific Journal of Management, 30(1): 231-249.

Lau, C.-M. 2002a. Asia Pacific Journal of Management: First issue 2002 introductory remarks. Asia Pacific Journal of Management, 19(1): 7-8.

Lau, C.-M. 2002b. Asian management research: Frontiers and challenges. Asia Pacific Journal of Management, 19(2-3): 171-178.

Lau, C.-M. 2007. The first decade of the Asia Academy of Management. Asia Pacific Journal of Management, 24(4): 401-410.

Law, K. S., Wong, C.-S., Huang, G.-H., \& Li, X. 2008. The effects of emotional intelligence on job performance and life satisfaction for the research and development scientists in china. Asia Pacific Journal of Management, 25(1): 51-69.

Lee, S. A. 2007. APJM and NUS, 1980-90. Asia Pacific Journal of Management, 24(4): 395-396.

Leung, K., Chen, Z., Zhou, F., \& Lim, K. 2014. The role of relational orientation as measured by face and renqing in innovative behavior in china: An indigenous analysis. Asia Pacific Journal of Management, 31(1): 105-126.

Leydesdorff, L., \& Meyer, M. 2003. The triple helix of university-industry-government relations: Introduction to the topical issue. Scientometrics, 58(2): 191-203.

Li, J. J. 2005. The formation of managerial networks of foreign firms in china: The effects of strategic orientations. Asia Pacific Journal of Management, 22(4): 423-443.

Li, J., \& Kozhikode, R. K. 2008. Knowledge management and innovation strategy: The challenge for latecomers in emerging economies. Asia Pacific Journal of Management, 25(3): 429-450.

Li, P. P. 2007. Social ties, social capital, and social behavior: Toward an integrative model of informal exchange. Asia Pacific Journal of Management, 24(2): 227-246.

Li, P. P. 2012. Toward an integrative framework of indigenous research: The geocentric implications of yinyang balance. Asia Pacific Journal of Management, 29(4): 849-872.

Li, S., \& Scullion, H. 2006. Bridging the distance: Managing cross-border knowledge holders. Asia Pacific Journal of Management, 23(1): 71-92.

Li, Y. 2011. Emotions and new venture judgment in China. Asia Pacific Journal of Management, 28(2): 277298.

Li, Y., \& Ahlstrom, D. 2016. Emotional stability: A new construct and its implications for individual behavior in organizations. Asia Pacific Journal of Management, 33(1): 1-28.

Li, Y., Ahlstrom, D., \& Ashkanasy, N. M. 2010. A multilevel model of affect and organizational commitment. Asia Pacific Journal of Management, 27(2): 193-213.

Li, Y., Ashkanasy, N. M., \& Ahlstrom, D. 2014a. The rationality of emotions: A hybrid process model of decision-making under uncertainty. Asia Pacific Journal of Management, 31(1): 293-308.

Li, Y., Chen, H., Liu, Y., \& Peng, M. W. 2014b. Managerial ties, organizational learning, and opportunity capture: A social capital perspective. Asia Pacific Journal of Management, 31(1): 271-291. 
Li, Y., Chun, H., Ashkanasy, N. M., \& Ahlstrom, D. 2012. A multi-level study of emergent group leadership: Effects of emotional stability and group conflict. Asia Pacific Journal of Management, 29(2): 351-366.

Li, Y., Sun, Y., \& Liu, Y. 2006. An empirical study of SOEs' market orientation in transitional China. Asia Pacific Journal of Management, 23(1): 93-113.

Li, Y., Yao, F. K., \& Ahlstrom, D. 2015. The social dilemma of bribery in emerging economies: A dynamic model of emotion, social value, and institutional uncertainty. Asia Pacific Journal of Management, 32(2): 311-334.

Liden, R. C. 2012. Leadership research in Asia: A brief assessment and suggestions for the future. Asia Pacific Journal of Management, 29(2): 205-212.

Lim, K. G. 2007. The Asia Pacific Journal of Management between 1992 and 1995. Asia Pacific Journal of Management, 24(4): 397-400.

Lin, J., \& Si, S. X. 2010. Can guanxi be a problem? Contexts, ties, and some unfavorable consequences of social capital in China. Asia Pacific Journal of Management, 27(3): 561-581.

Ling, Y.-H. 2013. The influence of intellectual capital on organizational performance-knowledge management as moderator. Asia Pacific Journal of Management, 30(3): 937-964.

Liu, Y., Chen, Y. J., \& Wang, L. C. 2017. Family business, innovation and organizational slack in Taiwan. Asia Pacific Journal of Management, 34(1): 193-213.

Liu, Y., Wang, L. C., Zhao, L., \& Ahlstrom, D. 2013. Board turnover in Taiwan's public firms: An empirical study. Asia Pacific Journal of Management, 30(4): 1059-1086.

López-Duarte, C., Vidal-Suárez, M. M., González-Díaz, B., \& Rosa-Reis, N. 2016. Understanding the relevance of national culture in international business research: A quantitative analysis. Scientometrics, 108(3): 1553-1590.

Lu, J. W., \& Ma, X. 2015. Partner resource asymmetry and IJV survival. Asia Pacific Journal of Management, 32(4): 1039-1064.

Lu, Y., \& Yao, J. 2006. Impact of state ownership and control mechanisms on the performance of group affiliated companies in China. Asia Pacific Journal of Management, 23(4): 485-503.

Lunnan, R., \& Zhao, Y. 2014. Regional headquarters in China: Role in MNE knowledge transfer. Asia Pacific Journal of Management, 31(2): 397-422.

Ma, X., Yao, X., \& Xi, Y. 2006. Business group affiliation and firm performance in a transition economy: A focus on ownership voids. Asia Pacific Journal of Management, 23(4): 467-483.

Martinez, M. A., Herrera, M., López-Gijón, J., \& Herrera-Viedma, E. 2014. H-Classics: Characterizing the concept of citation classics through H-index. Scientometrics, 98(3): 1971-1983.

Mathews, J. A. 2006. Dragon multinationals: New players in $21^{\text {st }}$ century globalization. Asia Pacific Journal of Management, 23(1): 5-27.

Meyer, K. E. 2006. Asian management research needs more self-confidence. Asia Pacific Journal of Management, 23(2): 119-137.

Meyer, K. E., \& Thaijongrak, O. 2013. The dynamics of emerging economy MNEs: How the internationalization process model can guide future research. Asia Pacific Journal of Management, 30(4): 1125-1153.

Nair, A., Guldiken, O., Fainshmidt, S., \& Pezeshkan, A. 2015. Innovation in India: A review of past research and future directions. Asia Pacific Journal of Management, 32(4): 925-958.

Ngo, H., Loi, R., Foley, S., Zheng, X., \& Zhang, L. 2013. Perceptions of organizational context and job attitudes: The mediating effect of organizational identification. Asia Pacific Journal of Management, 30(1): 149-168.

Olk, P., \& Griffith, T. L. 2004. Creating and disseminating knowledge among organizational scholars: The role of special issues. Organization Science, 15(1): 120-129.

Ooi, K.-B., Cheah, W.-C., Lin, B., \& Teh, P.-L. 2012. TQM practices and knowledge sharing: An empirical study of Malaysia's manufacturing organizations. Asia Pacific Journal of Management, 29(1): 59-78.

Park, B. I. 2010. What matters to managerial knowledge acquisition in international joint ventures? High knowledge acquirers versus low knowledge acquirers. Asia Pacific Journal of Management, 27(1): 5579.

Peng, G. Z., \& Beamish, P. 2014. The effect of host country long term orientation on subsidiary ownership and survival. Asia Pacific Journal of Management, 31(2): 423-453.

Peng, K. Z. 2017. Responding to emotions in China: Gender differences and the emotion-job outcome relationship. Asia Pacific Journal of Management, 34(2): 443-460.

Peng, M. W. 2005. Perspectives-from China strategy to global strategy. Asia Pacific Journal of Management, 22(2): 123-141.

Peng, M. W. 2007a. Celebrating 25 years of Asia Pacific management research. Asia Pacific Journal of Management, 24(4): 385-393. 
Peng, M. W. 2007b. Globalizing the Asia Pacific Journal of Management. Asia Pacific Journal of Management, 24(1): 1-7.

Peng, M. W. 2008. More progress at APJM. Asia Pacific Journal of Management, 25(1): 1-4.

Peng, M. W. 2009a. APJM is now included in SSCI. Asia Pacific Journal of Management, 26(1): 1-3.

Peng, M. W. 2009b. Passing the torch. Asia Pacific Journal of Management, 26(4): 611-616.

Peng, M. W., \& Zhou, J. Q. 2005. How network strategies and institutional transitions evolve in Asia. Asia Pacific Journal of Management, 22(4): 321-336.

Peng, M. W., \& Zhou, J. Q. 2006. Most cited articles and authors in global strategy research. Journal of International Management, 12: 490-508.

Peng, M. W., Li, Y., Xie, E., \& Su, Z. 2010. CEO duality, organizational slack, and firm performance in China. Asia Pacific Journal of Management, 27(4): 611-624.

Piwowar, H. A. 2013. Altmetrics: Value all research products. Nature, 493(7431): 159-159.

Pleggenkuhle-Miles, E., Aroul, R., Sun, S. L., \& Su, Y. 2007. The adolescence of Asia management research: APJM, 1997-2006. Asia Pacific Journal of Management, 24: 467-489.

Prabhu, J., \& Jain, S. 2015. Innovation and entrepreneurship in India: Understanding jugaad. Asia Pacific Journal of Management, 32(4): 843-868.

Priem, J., Piwowar, H. A., \& Hemminger, B. M. 2012. Altmetrics in the wild: Using social media to explore scholarly impact. arXiv preprint. arXiv:1203.4745.

Puffer, S. M., McCarthy, D. J., Jaeger, A. M., \& Dunlap, D. 2013. The use of favors by emerging market managers: Facilitator or inhibitor of international expansion?. Asia Pacific Journal of Management, 30(2): 327-349.

Quer, D., Claver, E., \& Rienda, L. 2007. Business and management in China: A review of empirical research in leading international journals. Asia Pacific Journal of Management, 24(3): 359-384.

Quer, D., Claver, E., \& Rienda, L. 2012. Political risk, cultural distance, and outward foreign direct investment: Empirical evidence from large chinese firms. Asia Pacific Journal of Management, 29(4): 1089-1104.

Rousseau, R. 2006. New developments related to the Hirsch index. Retrieved from http://eprints.rclis. org/archive/00006376/

Sauerwald, S., \& Peng, M. W. 2013. Informal institutions, shareholder coalitions, and principal-principal conflicts. Asia Pacific Journal of Management, 30(3): 853-870.

Schubert, A. 2009. Using the H-index for assessing single publications. Scientometrics, 78(3): 559-565.

Sharma, P., \& Chua, J. H. 2013. Asian family enterprises and family business research. Asia Pacific Journal of Management, 30(3): 641-656.

Shih, C.-T., \& Chuang, C.-H. 2013. Individual differences, psychological contract breach, and organizational citizenship behavior: A moderated mediation study. Asia Pacific Journal of Management, 30(1): 191210.

Singh, K. 2002. Message from the Editor. Asia Pacific Journal of Management, 19: 5.

Stan, C. V., Peng, M. W., \& Bruton, G. D. 2014. Slack and the performance of state-owned enterprises. Asia Pacific Journal of Management, 31(2): 473-495.

Starbuck, W. 1994. Journals ranked by citations per article. Working paper, NYU Stern School of Business, New York.

Su, Y.-S., Tsang, E. W. K., \& Peng, M. W. 2009. How do internal capabilities and external partnerships affect innovativeness?. Asia Pacific Journal of Management, 26(2): 309-331.

Sun, W., Xu, A., \& Shang, Y. 2014. Transformational leadership, team climate, and team performance within the NPD team: Evidence from China. Asia Pacific Journal of Management, 31(1): 127-147.

Syed, J. 2008. A context-specific perspective of equal employment opportunity in Islamic societies. Asia Pacific Journal of Management, 25(1): 135-151.

Syed, J., \& Pio, E. 2010. Veiled diversity? Workplace experiences of muslim women in Australia. Asia Pacific Journal of Management, 27(1): 115-137.

Tahamtan, I., Afshar, A. S., \& Ahamdzadeh, K. 2016. Factors affecting number of citations: A comprehensive review of the literature. Scientometrics, 107: 1195-1225.

Tang, J. 2010. How entrepreneurs discover opportunities in China: An institutional view. Asia Pacific Journal of Management, 27(3): 461-479.

Tang, Z., \& Tang, J. 2012. Entrepreneurial orientation and SME performance in china's changing environment: The moderating effects of strategies. Asia Pacific Journal of Management, 29(2): 409-431.

Treviño, L. J., Mixon, Jr., F. G., Funk, C. A., \& Inkpen, A. C. 2010. A perspective on the state of the field: International business publications in the elite journals as a measure of institutional and faculty productivity. International Business Review, 19: 378-387. 
Tung, R. L. 2005. Perspectives - New era, new realities: Musings on a new research agenda... from an old timer. Asia Pacific Journal of Management, 22(2): 143-157.

Tung, R. L., \& Chung, H. F. L. 2010. Diaspora and trade facilitation: The case of ethnic Chinese in Australia. Asia Pacific Journal of Management, 27(3): 371-392.

van Essen, M., van Oosterhout, J. (Hans), \& Carney, M. 2012. Corporate boards and the performance of Asian firms: A meta-analysis. Asia Pacific Journal of Management, 29(4): 873-905.

Wang, L., Hinrichs, K. T., Prieto, L., \& Howell, J. P. 2013. Five dimensions of organizational citizenship behavior: Comparing antecedents and levels of engagement in China and the US. Asia Pacific Journal of Management, 30(1): 115-147.

Wei, F., \& Si, S. 2013. Tit for tat? Abusive supervision and counterproductive work behaviors: The moderating effects of locus of control and perceived mobility. Asia Pacific Journal of Management, 30(1): 281-296.

Welch, C., Plakoyiannaki, E., Piekkari, R., \& Paavilainen-Mäntymäki, E. 2013. Legitimizing diverse uses for qualitative research: A rhetorical analysis of two management journals. International Journal of Management Reviews, 15(2): 245-264.

Weller, K. 2015. Social media and altmetrics: An overview of current alternative approaches to measuring scholarly impact. In I. Welpe, J. Wollersheim, S. Ringelhan, \& M. Osterloh (Eds.). Performance assessment and professional development in university teaching: 261-276. Cham: Springer.

Wouters, P., \& Costas, R. 2012. Users, narcissism and control: Tracking the impact of scholarly publications in the $21^{\text {st }}$ century. Utrecht: SURF foundation.

Wu, J., Li, S., \& Li, Z. 2013. The contingent value of CEO political connections: A study on IPO performance in China. Asia Pacific Journal of Management, 30(4): 1087-1114.

Wu, W.-P., \& Leung, A. 2005. Does a micro-macro link exist between managerial value of reciprocity, social capital and firm performance? The case of SMEs in China. Asia Pacific Journal of Management, 22(4): 445-463.

Yang, J. Y., \& Li, J. 2008. The development of entrepreneurship in China. Asia Pacific Journal of Management, 25(2): 335-359.

Yang, X., Jiang, Y., Kang, R., \& Ke, Y. 2009. A comparative analysis of the internationalization of Chinese and Japanese firms. Asia Pacific Journal of Management, 26: 141-162.

Yeung, H. W. C. 2006. Change and continuity in Southeast Asian ethnic Chinese business. Asia Pacific Journal of Management, 23(3): 229-254.

Young, M. N., Tsai, T., Wang, X., Liu, S., \& Ahlstrom, D. 2014. Strategy in emerging economies and the theory of the firm. Asia Pacific Journal of Management, 31(2): 331-354.

Yu, B., Hao, S., Ahlstrom, D., Si, S., \& Liang, D. 2014. Entrepreneurial firms' network competence, technological capability, and new product development performance. Asia Pacific Journal of Management, 31(3): 687-704.

Zhan, W., \& Chen, R. 2013. Dynamic capability and IJV performance: The effect of exploitation and exploration capabilities. Asia Pacific Journal of Management, 30(2): 601-632.

Zhang, J., \& Ma, H. 2009. Adoption of professional management in Chinese family business: A multilevel analysis of impetuses and impediments. Asia Pacific Journal of Management, 26(1): 119-139.

Zheng, C., \& Lamond, D. 2010. Organisational determinants of employee turnover for multinational companies in Asia. Asia Pacific Journal of Management, 27(3): 423-443.

Zhou, K. Z., \& Li, C. B. 2007. How does strategic orientation matter in Chinese firms?. Asia Pacific Journal of Management, 24(4): 447-466.

Zhu, Y., Sun, L.-Y., \& Leung, A. S. M. 2014. Corporate social responsibility, firm reputation, and firm performance: The role of ethical leadership. Asia Pacific Journal of Management, 31(4): 925-947.

Zhu, Y., Wittmann, X., \& Peng, M. W. 2012. Institution-based barriers to innovation in SMEs in China. Asia Pacific Journal of Management, 29(4): 1131-1142.

Cristina López-Duarte ( $\mathrm{PhD}$, University of Oviedo) is currently an Associate Professor of management and international business at the University of Oviedo (Spain). Her primary research focuses on international strategy, foreign direct investments, and international strategic alliances, as well as on intercultural issues and their impact on international growth decisions. She consistently participates in research projects supported by national and international institutions. Her research has been published in international business and management journals such as the International Journal of Management Reviews, International Business Review, Journal of World Business, International Journal of Human Resource Management, and Management International Review. 
Marta M. Vidal-Suárez ( $\mathrm{PhD}$, University of Oviedo) is an Associate Professor of management and international business at the University of Oviedo (Spain). Her primary research focuses on international and global strategic alliances, as well as on intercultural issues and their impact on internationalization decisions and international strategy. She consistently participates in research projects supported by national and international institutions. Her research has been published in international business and management journals such as the Long Range Planning, International Journal of Management Reviews, International Business Review, Journal of World Business, International Journal of Human Resource Management, and European Business Review.

Belén González-Díaz (PhD, University of Oviedo) is a Senior Lecturer of accounting at the University of Oviedo (Spain). She has been a Visiting Scholar at American and European universities. Her research is focused on public administration and international business. Results from this research have been published in internationally indexed journals like the Spanish Journal of Finance and Accounting, Administration \& Society, International Review of Administrative Sciences, Scientometrics, Journal of World Business, Cross Cultural Management, and International Journal of Management Reviews. 